\title{
33. DIAGENETIC POLYMETALLIC CRUSTS AT SITES 550 AND 548 OF LEG 80, NORTHEASTERN ATLANTIC OCEAN ${ }^{1}$
}

\author{
Anne Marie Karpoff, Centre de Sédimentologie et Géochimie de la Surface, \\ Centre National de la Recherche Scientifique \\ Maurice Bourbon, École Nationale Supérieure des Mines \\ Bruno Ancel, Centre de Sédimentologie et Géochimie de la Surface, Centre National de la Recherche Scientifique \\ and \\ Pierre Charles de Graciansky, École Nationale Supérieure des Mines²
}

\begin{abstract}
At Sites 548 and 550 of DSDP Leg 80 several condensed sedimentary sections contain various types of polymetallic crusts. The relationships between mineralogic and geochemical data in the sections have been studied in the context of the biostratigraphic and sedimentologic results. The diagenetic evolution during periods of low accumulation rate varies according to depth and sedimentary environment. At Site 548 on the continental margin, the phosphatic and manganiferous crusts are similar to those related to upwelling influences before Late Cretaceous deposition. At Site 550 the upper Paleocene cherts, deposited directly on oceanic crust, are overlain by pelagic brown clays containing diagenetic manganiferous concretions characterized by very high $\mathrm{Sr}$ and $\mathrm{Ba}$ contents. The origin of these small nodules is probably related to the authigenesis of fecal pellets. The upper Eocene indurated section is made up of authigenic zeolites, clays, and $\mathrm{Fe}-\mathrm{Mn}$ phases and is similar to the volcanic-sedimentary deposits described in deep basins and seamounts of the Pacific. These crusts and a polynucleated nodule within the overlying sediments have geochemical characteristics (high $\mathrm{Ni}, \mathrm{Co}$, and $\mathrm{Cu}$ contents) similar to those formed in the deep ocean under volcanic influences during periods of low sedimentation rates or sedimentary hiatuses.

Volcaniclastic material is ubiquitous and peculiarly abundant in Eocene sections and can be related to the volcanic formation of Iceland in the North Atlantic.
\end{abstract}

\section{INTRODUCTION}

Among the objectives of Leg 80 was the reconstruction of the evolution of paleoenvironments at various depths across a starved margin and on the adjacent oceanic crust during the synrift and postrift periods. The Goban Spur transect, located on the northeastern Atlantic margin off Cornwall, Britain, was chosen for this purpose. Four sites (Figs. 1 and 2) were drilled at increasing depths from the upper slope (Site 548, water depth $1256 \mathrm{~m}$ ) across the Pendragon Escarpment (Sites 549 and 551) to the depth of oceanic crust (Site 550, water depth $4432 \mathrm{~m}$ ). Sites 548 and 550 provide condensed or shortened sections of various ages which are underlain by metalliferous crusts.

At the deepest Site 550, one of these peculiar levels is composed of small manganiferous nodules agglomerated within brown clays of late Paleocene age. Another 1.5-m-thick layer dated as middle Eocene to late Oligocene consists of several crusts made of indurated clayey sediment rich in volcaniclastic material and of $\mathrm{Mn}$ oxides (Plate 1). At the shallowest Site 548, a phosphatic and partly manganiferous layer forms a $3-\mathrm{cm}$-thick crust at the bottom of the upper Campanian chalk column.

\footnotetext{
${ }^{1}$ Graciansky, P. C. de, Poag, C. W., et al., Init. Repts. DSDP, 80: Washington (U.S. Govt. Printing Office).

2 Addresses: (Karpoff and Ancel) Centre de Sédimentologie et Géochimie de la Surface, CNRS, Strasbourg, France; (Bourbon and Graciansky) École Nationale Supérieure des Mines. Paris, France.
}

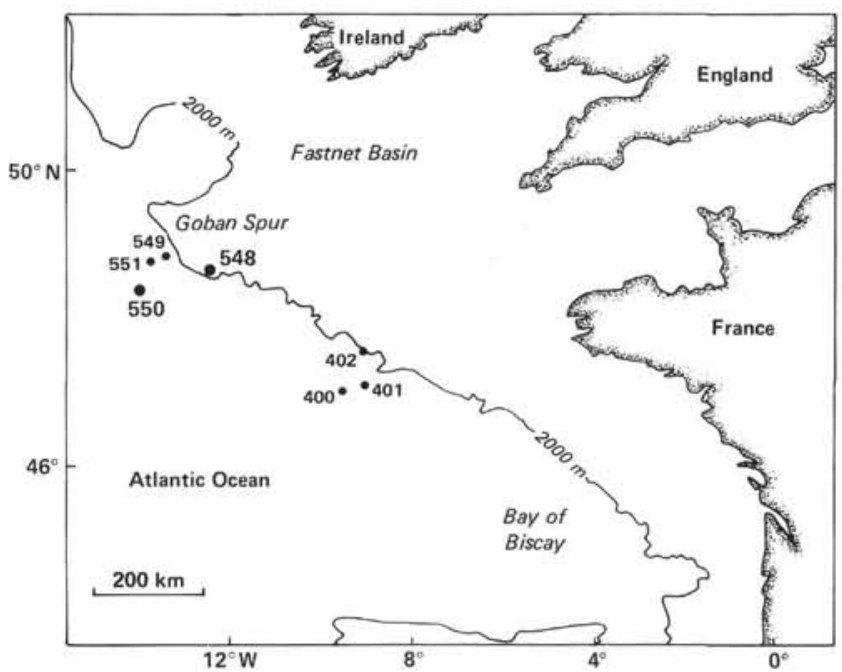

Figure 1. Location sketch map of Sites 548 and 550 on the northwestern European continental margin. Other sites from Leg 80 (549, $551)$ and Leg 48 (400-402) are shown for reference.

Unfortunately, a $20-\mathrm{m}$ interval is missing between the base of the Upper Cretaceous sequence and the Hercynian basement, making the relationship between the crust and the over- and underlying beds uncertain.

Studies on metalliferous crusts and concretions using standard sedimentologic, mineralogic, and geochemical methods help to establish the authigenic and diagenetic processes of their formation. Comparisons with similar 


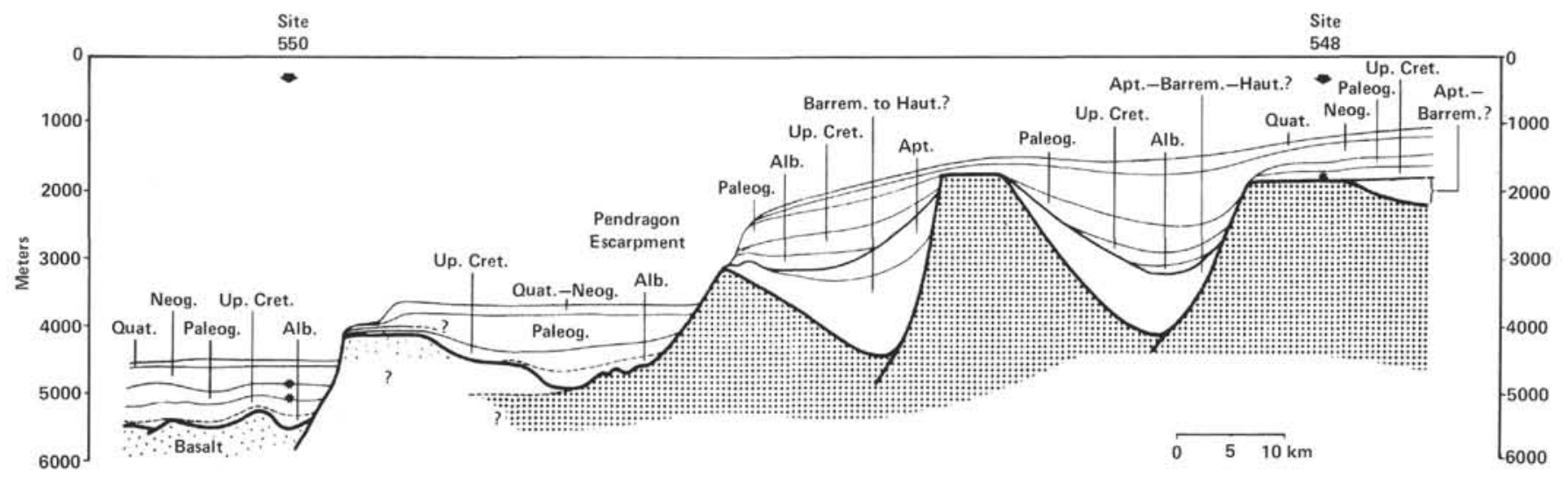

Figure 2. Diagrammatic cross section of the Goban Spur continental margin. ${ }^{*}=$ location of encrusting layers studied.

facies from the Pacific and Atlantic oceans and with fossil equivalents from the Tethys Sea (now exposed in the Alps) provide useful information for paleoenvironmental interpretation in the northeastern Atlantic.

\section{SITE 550}

\section{Lithology}

The diverse sedimentary units recovered at Site 550 are described in the site chapter in this volume. From top to bottom, the lithologic units studied here are as follows:

Unit 1b. Lower Miocene and middle Oligocene marly oozes and chalks rich in nannofossils (Cores 23-5 to 242, $34 \mathrm{~cm}$ ); a Mn-rich nodule (Fig. 3) occurs in Core 24-1 at $100 \mathrm{~cm}$.

Unit 2a. Lower Oligocene to upper Eocene condensed, encrusted, clayey, Mn oxide-rich section (Cores 24-2, 34 $\mathrm{cm}$ to $24-2,150 \mathrm{~cm}$; Plate 1) and lower Eocene pelagic mudstones and marly calcareous oozes (Cores 24-3 to 34-3).

Unit 2b. Upper Paleocene mudstones (Cores 34-4 to 36-3) and pelagic brown claystones with small Mn nodules (Core 36-3, 31-95 cm).

Unit 3a. Upper Paleocene chalk (Core $36-3,95 \mathrm{~cm}$ to Core 40) with interbedded cherts.

This sedimentary section shows several hiatuses and condensation events related to dissolution processes. In Core 24 between Sections 1 and 4, evidence for two major hiatuses have been established (site report, this volume). One apparently occurred in early middle Oligocene $(24-1,135 \mathrm{~cm})$, and the other in middle and late Eocene $(24-2,62-95 \mathrm{~cm})$; both are marked by clayey deposits overlain by a Mn crust. Evidence for a short Paleocene hiatus (2-3 m.y. ago) occurs near the limit between Units $2 \mathrm{~b}$ and $3 \mathrm{a}$ on top of the brown clays. A schematic lithologic section is summarized in Figure 4.

\section{Mineralogy}

The mineralogy of the sedimentary deposits was defined by microscopic observation of smear slides of the bulk sediments, by observations of the coarse fraction ( $>63 \mu \mathrm{m}$ ), and by X-ray diffraction techniques on both

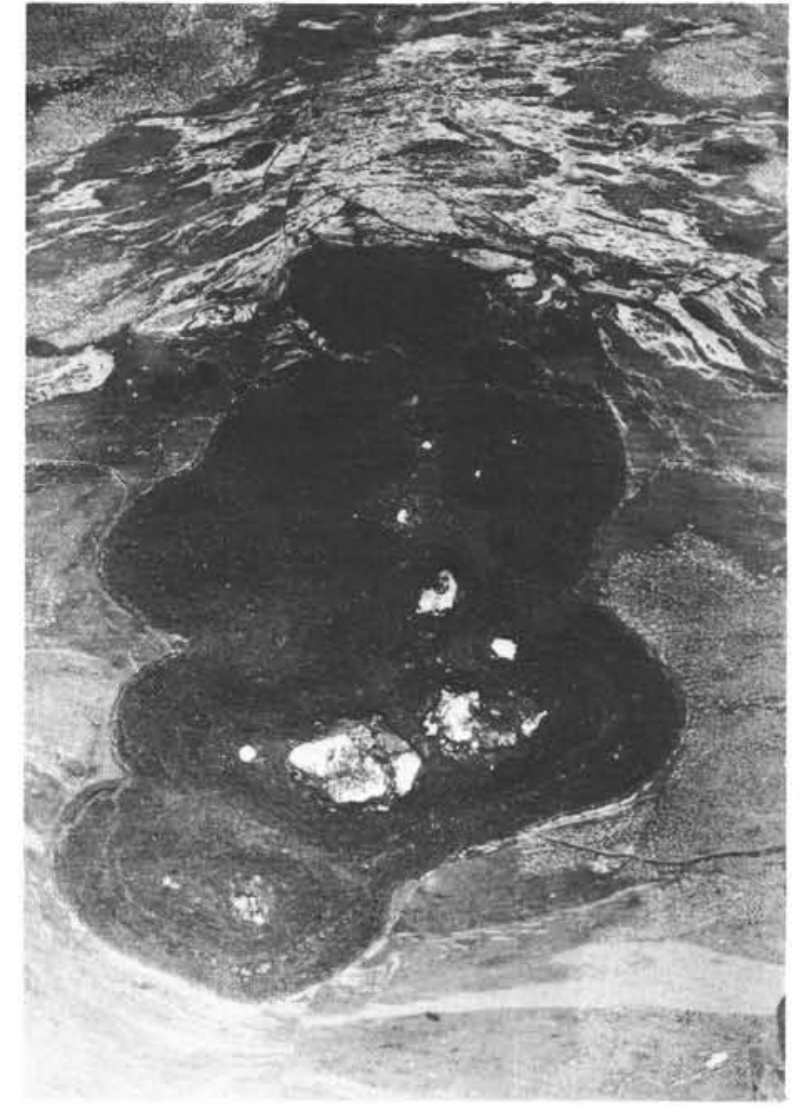

Figure 3. Photomicrograph (binocular reflected light) of thin section of Mn nodule within the Oligocene marly chalk (550-24-1, 97$100 \mathrm{~cm}$ ).

the bulk sediments and the clay fraction $(>2 \mu \mathrm{m})$. The results are shown in Figure 4.

\section{Smear Slides}

Microscopic investigations confirm prevalent biogenic calcareous and clay lithologies containing ubiquitous volcaniclastic fragments and glass that become most abundant in the encrusted level of Core 24 and in the Paleocene brown clays. Metallic oxides are coated with clay in samples from the indurated level and occur as 


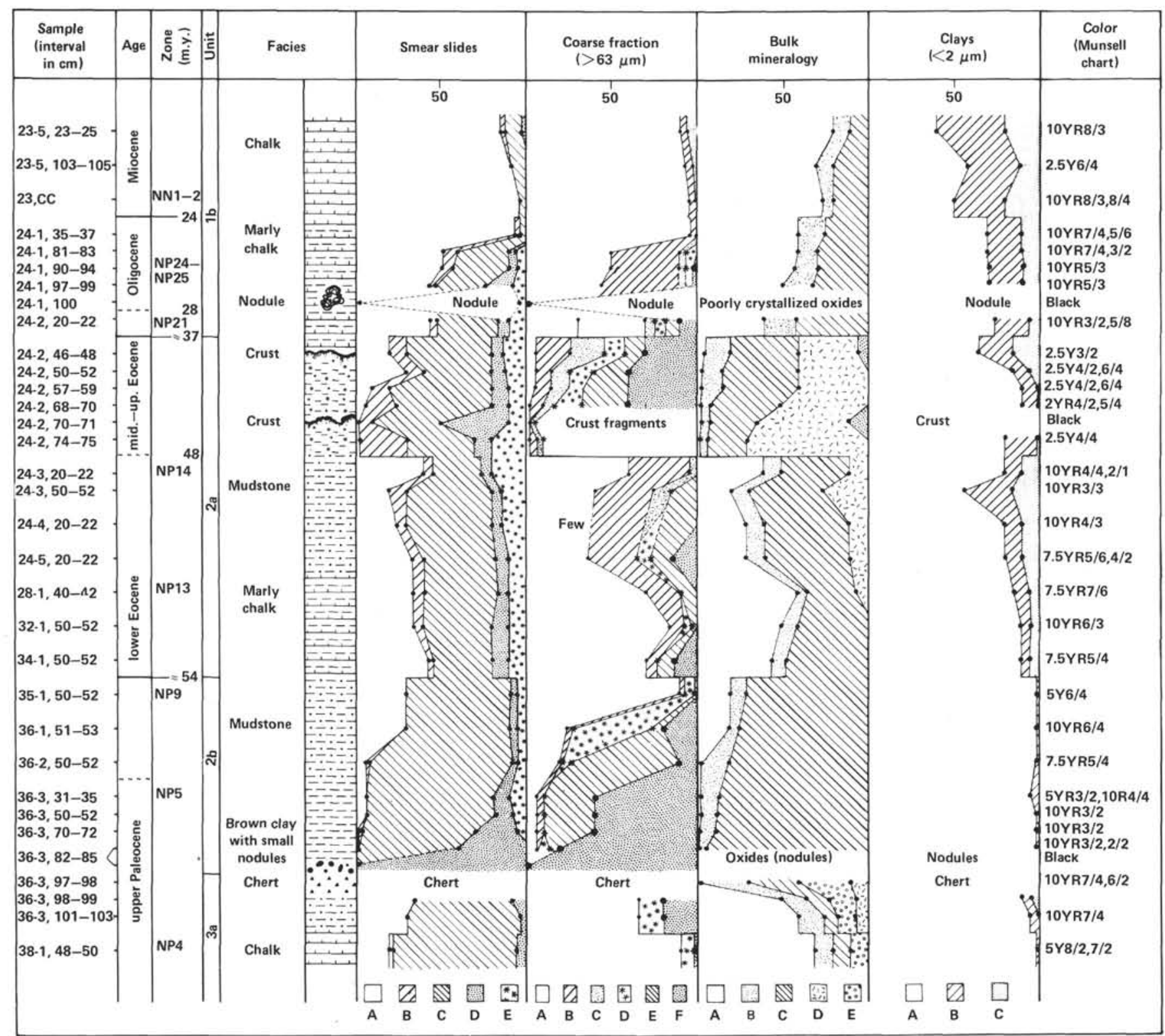

Figure 4. Schematic representation of sedimentologic and mineralogic data of sedimentary deposits at Site 550. Hiatuses indicated by wavy lines. Smear slide data: (A) calcareous organisms and carbonate unspecified; (B) siliceous organisms, sponge spicules, and teeth and fish remains; (C) clays; (D) oxides; (E) volcaniclastic components. Coarse fraction: (A) calcareous organisms; (B) sponge spicules, teeth, and fish remains; (C) quartz; (D) volcaniclastic components; (E) clay and/or zeolitic aggregates; (F) micronodules and oxides fragments. Bulk mineralogy (X-ray diffraction, semi-quantitative data): (A) calcite; (B) quartz; (C) clays; (D) zeolites; (E) opal-CT. Clays (clay fraction composition by X-ray diffraction, semi-quantitative estimation): (A) smectites; (B) illite and mixed-layer clays; (C) kaolinite.

globules and micronodules in the brown clays. Occurrence of very small zeolites is suspected in Section 2 of Core 24.

\section{Coarse Fraction}

The sandy fraction is composed of calcareous organisms, abundant teeth and fish remains, and detrital compounds such as quartz and phyllite. In places zeolitic clay aggregates, palagonite, and volcanic glass fragments are associated with Mn oxide-coated particles and $\mathrm{Mn}$ micronodules. The nature of the volcanic debris is similar to ash found in the Eocene sequence described by Knox (this volume). The upper Eocene Mn crusts are differentiated from the Paleocene brown clays containing Mn concretions by the following characteristics:

1. The upper Eocene indurated volcanic-sedimentary section with Mn dentritic coatings and crusts has a large coarse fraction made up of heterogeneous particles of various sizes derived from the disaggregated lithified deposit. Detrital quartz and phyllite are the finest grains in the section and make up most of the fine sandy fraction; their presence correlates with a low content of carbonate and biogenic debris. The larger fragments (up to $1 \mathrm{~cm}$ ) are $\mathrm{Mn}$-coated clays and zeolitic aggregates. Mn oxides occur as diffused impregnated dendrites or as colloform and layered structures similar to those de- 
scribed by Sorem and Fewkes (1977) for deep sea nodules and crusts. The structure of the indurated levels from Core 24 appears to be similar to those of crusts and volcanic-sedimentary deposits described in samples from the Pacific Ocean by Morgenstein (1967), Hoffert, Karpoff, et al. (1978), and Karpoff et al. (1980).

2 . The coarse fraction from the Paleocene brown clays is more homogeneous; it is made up of ovoids and small, buck-shot-like nodules of various sizes (up to $5 \mathrm{~mm}$ ) and pink zeolitic clay aggregates and trace amounts of volcaniclastic debris. The internal structure of the small nodules is massive, and the nodules do not show columnar structures or concentric layering in section.

SEM investigations on broken small nodules establish that they consist only of biogenic fragments completely replaced by Mn oxides. Within the "mash" of organic debris some diatom and sponge remains are recognizable (Plate 2). The occurrence of siliceous tests in marine $\mathrm{Mn}$ encrustations has been described elsewhere, but colloform, columnar, botryoidal, and layered features are also always present (Friedrich, 1976; Burns and Burns, 1979; Moore et al., 1981).

Within the small nodules, all the organisms are epigenized and coated by $\mathrm{Mn}$ oxides. In places the $\mathrm{Mn}$ is in various well-crystallized forms of todorokite (Plate 3 ). Clusters of these radiating, needle-like crystals are similar to those observed by Margolis et al. (1979). The buckshot-like concretions can be interpreted as fecal pellets diagenetically replaced by todorokite. This hypothesis is supported by the characteristic size and shape of the nodules and by their lack of internal features. Fecal pellets composed of silt and clay mixed with biogenic siliceous debris have been recovered in deep sea cores such as those described by Thompson and Whelan (1980) in Miocene-Pleistocene sediments.

\section{X-Ray Analyses}

\section{Methods}

The X-ray diffraction charts from unoriented powders have been obtained using bulk sediments under the following conditions: $\mathrm{Cu} \mathrm{K} \alpha$ radiation, $\mathrm{Ni}$ filter, $40 \mathrm{kV} /$ $18 \mathrm{~mA}, 0.1-1^{\circ}$ slits, $1^{\circ} / \mathrm{min}$ speed. The identification of clay minerals in the $>2 \mu \mathrm{m}$ fraction was made on three types of oriented aggregates: untreated, ethylene glycol treated, and heated, according to the standard methods of the Institut de Géologie in Strasbourg (Weber and Larqué, 1978). Some fine fractions $(>63 \mu \mathrm{m}$ and $>2$ $\mu \mathrm{m})$ were also studied by microdiffraction on isolated particles by transmission electron microscopy (TEM) (Phillips EM 300) using the method of Trauth et al. (1977).

\section{Results}

\section{Bulk Sediment}

The X-ray diffraction diagrams show prevalent calcite, clays, and scarce quartz in the upper Eocene indurated crusts (Core 24) as well as minor amounts of the zeolite phillipsite. Traces of goethite and apatite were also discernible. In the brown clays (Core 36 ), clinop- tilolite occurs in some samples associated with small amounts of opal-CT and cristobalite (Fig. 4).

\section{Clay Fraction Composition}

The clay fraction from the Miocene to upper Paleocene deposits consists of smectites, illites, small amounts of kaolinite, and scarce mixed-layer clays (Fig. 4). Smectites become prevalent in the indurated Eocene volcanic-sedimentary section. The clay assemblage is relatively constant throughout the lower Eocene section, with only a slight increase of smectite toward the base. The Eocene/Paleocene boundary is marked by the disappearance of kaolinite and a low illite content. The Paleocene deposits below the brown clay sequence and the chert layer contain abundant smectites (Chennaux et al., this volume), as did the clay fraction in the Paleocene deposits previously described at sites of Leg 48 (Latouche and Maillet, 1979).

\section{TEM Investigations on the Fine Fraction}

The microscopic analyses made on the dispersed fine fraction from the samples just described establish the morphologic differences between the clay particles and the associated minerals and further define the authigenic and diagenetic processes.

The uppermost Unit 1b (Miocene-upper Oligocene) contains prevalent detrital clays with altered illite having fibrous outlines and scarce palygorskite fibers associated with large flaky smectite grains (Plate 4, Figs. 1 and 2).

The middle-upper Eocene indurated level contains smectites that differ from those of the overlying deposits (Plate 4, Figs. 3, 4, and 5). The smectite particles often have irregular outlines and are fringed by poorly crystallized iron oxide aggregates (Schwertmann and Taylor, 1977, 1979; Kohyama and Sudo, 1975). Such a morphology is typical of authigenic smectites forming in association with volcanogenic sediments (Hoffert, 1980; Karpoff et al., 1980; Karpoff, 1984). The fine fraction of the encrusted samples is made up of crystal laths of Mn minerals such as todorokite (Chukhrov et al., 1980; Arrehenius and Tsai, 1981) associated with phyllosilicates.

The clay fraction from lower Eocene marly chalk (Unit 2a: Fig. 4) contains prevalent smectites forming large particles with slightly rolled-up edges and small flaky particles. Palygorskite is present (Plate 5, Fig. 1). These associations and morphologies are similar to those of clays from partially dissolved calcareous oozes described by Hoffert (1980).

The clay fraction of the upper Paleocene mudstones (Unit 2b) contains aggregates of siliceous globules associated with large smectites (Plate 5, Figs. 2-4). Some of these lumplike aggregates are surrounded by thin sheets of authigenic phyllosilicate.

In the brown clay section, the clay minerals (Plate 6) are predominantly smectites with slightly rolled-up edges similar to those from red clays described by Hoffert (1980). Small bunches of siliceous granules occur, and the Mn crystals are well developed. The diffraction pattern on the Mn laths (Plate 6, Figs. 3 and 4) confirms 
that their mineralogy is similar to todorokite (Arrhenius and Tsai, 1981).

The granular cristobalite lepispheres and siliceous aggregates are abundant in the fine fraction from the cherty level of the upper Paleocene section and are surrounded by and associated with thin authigenic sheets of smectite (Plate 7).

\section{Mineral Paragenesis: Signature of Authigenic and Diagenetic Evolution}

The conditions of formation of authigenic clinoptilolite and phillipsite have often been debated. These zeolites are apparently related to volcanic influences and to the diagenetic alteration of pelagic sediments (Bonatti, 1972; Hein and Scholl, 1978; Kastner and Stonecipher, 1978). The concomitant argillization and zeolitization of marine volcaniclasts have been described (Arrhenius, 1963; Honnorez, 1978; Hoffert, Karpoff, et al., 1978; Petzing and Chester, 1979; Karpoff et al., 1980, 1981; Taylor and Surdam, 1981). The diagenetic paragenesis of silica, zeolites, and phyllosilicates in the northwestern Atlantic was clearly established by Riech (1979) in sedimentary sequences at Sites 397 and 398 and by Harrison et al. (1979) in tuffaceous sediments at Sites 403 and 404.

The authigenic formation of cristobalite is related to the dissolution of biogenic opal in siliceous oozes, in volcanic glass, and occasionally in quartz (Peterson and von der Borch, 1965; Lancelot, 1973; Wise and Weaver, 1974; Klasik, 1975; Kastner et al., 1977; Louail, 1979; von Rad, 1979). Co-occurrence of cristobalite, opal-CT, and clinoptilolite was described by Jeans (1978), Chamley et al. (1979), Iijima et al. (1980), and Moncure et al. (1981).

Palygorskite in oceanic deposits appears to be mainly related to the siliceous nature of the sediments, but it is sometimes ascribed to the weathering of volcanic material or to the transformation of smectites (Hataway and Sachs, 1965; Couture, 1977; Donnelly and Merrill, 1977; Nathan and Flexer, 1977; Church and Velde, 1979; Latouche et al., 1979; Singer, 1979). Nevertheless, a detrital origin for palygorskite in the North Atlantic sediments is hypothesized by Chamley et al. (1979) and Debrabant et al. (1979).

In accordance with these studies, the mineralogical composition of the upper Paleocene brown clays suggests that it is a condensed deposit formed by the dissolution of a biogenic ooze during a period of a low rate of sediment accumulation and which had a slight volcanic contribution. This facies is comparable to the deep sea "red clays" (Hoffert, 1980; Karpoff, 1984); although the small Mn concentrations found in it (thought to be diagenetically transformed fecal pellets) make it unique. The overlying mudstone (Unit $2 \mathrm{~b}$ ) and cherty chalk (Unit 3a) facies result from the diagenetic transformation of siliceous nannofossil oozes. The condensed section of upper Eocene and its crusts are related to the alteration of volcanic compounds and specific authigeneses of silicates and oxides. The combination of two influences, that is, a dominant volcanic contribution and a low sedimentation rate and a hiatus, apparently resulted in the formation of indurated Mn crusts. A similar evolution was described in a volcanic-sedimentary sequence by Hoffert, Karpoff, et al. (1978).

\section{Geochemistry}

\section{Methods}

The geochemical data are from the same set of samples as previously discussed. Major element analyses were performed following the method described by Besnus and Rouault (1973) using arc spectrometry and an ARL quantometer. The sample was melted in a mixture of lithium tetraborate and introduced into a glycolated solvent. Trace elements were determined using an inductive coupled plasma technique (ICP-35000 C-ARL). Na and $\mathrm{K}$ were determined by emission spectrometry. The relative precision is $\pm 2 \%$ for major elements and $\pm 10 \%$ for trace elements.

\section{Results}

The bulk chemical data are presented in Tables 1, 2, and 3 for major elements, recalculated on $\mathrm{CaCO}_{3}$-free basis (correction for $\mathrm{CaO}=0 \%$ and equivalent $\mathrm{CO}_{2}$ total LOI at $1000^{\circ} \mathrm{C}$ ), and trace elements (ppm). The variations in prevalent major element and some trace element contents are shown in Figure 5.

In the carbonate-free phases, the metal contents are mostly constant throughout the upper Paleocene to lower Miocene sequence. There are higher contents of Fe and $\mathrm{Mn}$, however, in samples concentrated in metallic oxides, such as crusts, nodules, and brown clays. The trace elements $\mathrm{Ni}, \mathrm{Co}, \mathrm{Cu}$, and $\mathrm{Ba}$ occur in association with these metallic concentrations (e.g., $\mathrm{Ni}$ and $\mathrm{Ba}$ ) but their contents vary greatly. The silica content is mainly constant but increases slightly with the higher $\mathrm{Si} / \mathrm{Al}$ ratios (Table 1) near the bottom, corresponding to more siliceous clayey sediments and cherty layers.

\section{Strontium and Barium Contents}

$\mathrm{Ca}$ and $\mathrm{Sr}$ relationships, now well known in biogenic carbonates (Turekian, 1964; Renard et al., 1979; Karpoff, 1980; Karpoff et al., 1981), show the diagenetic evolution of Site 550 deposits (Fig. 6).

$\mathrm{Sr}$, released from dissolved biogenic phases, is taken up by secondary minerals such as clays, zeolites, and oxides. The low $\mathrm{Sr}$ content of Paleocene chalks results from the diagenesis of the previous calcareous oozes, whereas the overlying zeolitic cherty layer is enriched in strontium. The Mn concretions within the brown clays have unusually high $\mathrm{Sr}$ contents. In a similar way the upper Eocene volcanic-sedimentary sequence is richer in $\mathrm{Sr}$ than the over- and underlying deposits.

$\mathrm{Ba}$ contents show the same variations as $\mathrm{Sr}$ contents. Likewise, the Ba-bearing siliceous organisms supply the trace elements that are associated with the authigenic minerals (zeolites and oxides). Occurrence of $\mathrm{Ba}$ in biogenic phases is often cited (Turekian and Tausch, 1964; Burton, 1966; Boström et al., 1978; Gurwich et al., 1978). Volcanic or hydrothermal environments are sometimes suggested as sources of $\mathrm{Ba}$ concentrations (Bonatti et al., 1972). In the Site 550 deposits, the greater amounts 
Table 1. Bulk chemical analyses of sediments from Site 550 (in wt. \%).

\begin{tabular}{|c|c|c|c|c|c|c|c|c|c|c|c|c|c|c|}
\hline $\begin{array}{c}\text { Sample } \\
\text { (interval in } \mathrm{cm} \text { ) }\end{array}$ & $\mathrm{SiO}_{2}$ & $\mathrm{Al}_{2} \mathrm{O}_{3}$ & $\mathrm{MgO}$ & $\mathrm{CaO}$ & $\mathrm{Fe}_{2} \mathrm{O}_{3}$ & $\mathrm{Mn}_{3} \mathrm{O}_{4}$ & $\mathrm{TiO}_{2}$ & $\mathrm{Na}_{2} \mathrm{O}$ & $\mathrm{K}_{2} \mathrm{O}$ & $\begin{array}{l}\text { LOI at } \\
1000^{\circ} \mathrm{C}\end{array}$ & Total & $\mathrm{Si} / \mathrm{Al}$ & $\mathrm{Fe} / \mathrm{Mn}$ & $\mathrm{CaCO}_{3}$ \\
\hline $550-23-5,23-25$ & 11.4 & 3.7 & 0.76 & 44.6 & 1.5 & 0.247 & 0.14 & 0.44 & 0.08 & 36.93 & 99.80 & 3.08 & 6.07 & 79.6 \\
\hline $23-5,104-105$ & 20.2 & 6.4 & 1.30 & 37.3 & 2.2 & 0.327 & 0.21 & 0.68 & 0.43 & 30.13 & 99.18 & 3.16 & 6.73 & 66.6 \\
\hline $23, \mathrm{CC}$ & 14.0 & 4.5 & 1.01 & 42.0 & 1.6 & 0.237 & 0.16 & 0.46 & 0.07 & 35.10 & 99.14 & 3.11 & 6.75 & 75.0 \\
\hline $24-1,35-37$ & 28.9 & 7.9 & 1.70 & 29.7 & 3.0 & 0.365 & 0.28 & 0.93 & 0.94 & 26.43 & 100.15 & 3.66 & 8.22 & 53.0 \\
\hline $24-1,81-83$ & 29.6 & 7.7 & 1.43 & 28.8 & 3.0 & 0.413 & 0.30 & 1.09 & 1.27 & 25.61 & 99.21 & 3.84 & 7.26 & 51.4 \\
\hline $24-1,90-94$ & 25.6 & 7.0 & 1.23 & 31.7 & 2.6 & 0.369 & 0.25 & 0.96 & 1.23 & 28.55 & 99.49 & 3.66 & 7.05 & 56.6 \\
\hline $24-1,97-99$ & 27.7 & 7.3 & 1.25 & 29.4 & 2.6 & 0.313 & 0.25 & 1.00 & 1.58 & 28.34 & 99.73 & 3.79 & 8.31 & 52.5 \\
\hline $24-1,100-101^{\mathrm{a}}$ & 33.5 & 3.3 & 1.28 & 0.7 & 26.8 & 11.8 & 0.58 & 1.11 & 0.78 & 17.82 & 97.67 & 10.15 & 2.27 & 1.2 \\
\hline $24-2,20-22$ & 38.9 & 10.7 & 2.30 & 19.9 & 4.9 & 0.570 & 0.41 & 1.34 & 2.08 & 18.91 & 100.01 & 3.64 & 8.60 & 35.5 \\
\hline $24-2,46-48$ b & 55.1 & 15.4 & 3.12 & 1.0 & 6.6 & 6.25 & 0.41 & 2.19 & 2.62 & 7.59 & 100.28 & 3.58 & 1.06 & 1.8 \\
\hline $24-2,50-52$ & 56.8 & 15.8 & 2.74 & 0.8 & 7.5 & 1.09 & 0.51 & 2.24 & 3.54 & 6.99 & 98.01 & 3.59 & 6.88 & 1.4 \\
\hline $24-2,57-59$ & 59.1 & 16.9 & 2.65 & 1.1 & 6.0 & 0.538 & 0.53 & 2.26 & 3.71 & 6.77 & 99.56 & 3.50 & 11.15 & 2.0 \\
\hline $24-2,68-70$ & 59.0 & 17.1 & 2.54 & 1.1 & 5.5 & 0.928 & 0.48 & 2.88 & 3.97 & 7.13 & 100.63 & 3.45 & 5.93 & 2.0 \\
\hline $24-2,70-71^{\mathrm{c}}$ & 52.2 & 17.3 & 4.29 & 1.5 & 4.3 & 7.23 & 0.32 & 2.34 & 2.13 & 8.09 & 99.70 & 3.02 & 0.59 & 2.7 \\
\hline $24-2,74-75$ & 57.2 & 16.3 & 2.12 & 1.3 & 6.1 & 0.905 & 0.55 & 2.63 & 4.19 & 7.44 & 98.74 & 3.51 & 6.74 & 2.3 \\
\hline $24-2,74-75^{\mathrm{d}}$ & 58.4 & 16.5 & 1.52 & 0.5 & 3.4 & 0.457 & 0.27 & 4.02 & 5.33 & 8.84 & 99.24 & 3.54 & 7.44 & 0.9 \\
\hline $24-2,74-75^{\mathrm{e}}$ & 47.9 & 14.0 & 2.13 & 1.3 & 6.4 & 5.03 & 0.61 & 1.85 & 3.25 & 12.50 & 94.97 & 3.42 & 1.27 & 2.3 \\
\hline $24-3,20-22$ & 36.1 & 10.8 & 2.29 & 21.5 & 4.8 & 0.399 & 0.43 & 1.15 & 1.94 & 20.92 & 100.33 & 3.34 & 12.03 & 38.4 \\
\hline $24-3,50-52$ & 54.3 & 17.1 & 2.67 & 3.0 & 7.5 & 0.888 & 0.66 & 1.84 & 3.44 & 9.35 & 100.75 & 3.18 & 8.45 & 5.4 \\
\hline $24-4,20-22$ & 41.5 & 13.3 & 3.25 & 14.7 & 6.3 & 0.705 & 0.48 & 1.36 & 2.16 & 15.91 & 99.67 & 3.12 & 8.94 & 26.2 \\
\hline $24-4,20-22^{f}$ & 38.9 & 12.5 & 2.74 & 18.7 & 5.5 & 0.183 & 0.45 & 1.20 & 1.90 & 18.65 & 100.72 & 3.11 & 30.05 & 33.4 \\
\hline $24-5,20-21$ & 37.0 & 12.2 & 2.47 & 18.7 & 5.6 & 0.074 & 0.45 & 1.16 & 1.74 & 19.20 & 98.59 & 3.03 & 75.68 & 33.4 \\
\hline $24-5,21-22$ & 40.2 & 13.1 & 2.55 & 16.8 & 5.9 & 0.789 & 0.48 & 1.25 & 1.91 & 17.50 & 100.48 & 3.07 & 7.48 & 30.0 \\
\hline $28-1,40-42$ & 25.2 & 9.2 & 1.19 & 30.7 & 4.3 & 0.254 & 0.42 & 0.78 & 0.83 & 27.96 & 100.83 & 2.74 & 16.93 & 54.8 \\
\hline $32-1,50-52$ & 31.7 & 9.3 & 1.53 & 24.5 & 5.4 & 0.290 & 0.59 & 0.94 & 1.14 & 23.11 & 98.50 & 3.41 & 18.62 & 43.8 \\
\hline $34-1,50-52$ & 32.9 & 10.3 & 1.67 & 22.9 & 5.4 & 0.274 & 0.50 & 0.97 & 1.34 & 22.11 & 98.36 & 3.19 & 19.71 & 40.9 \\
\hline $35-1,50-52$ & 55.4 & 9.5 & 1.84 & 10.9 & 4.4 & 0.247 & 0.36 & 1.42 & 1.33 & 13.48 & 98.88 & 5.83 & 17.81 & 19.5 \\
\hline $35-1,50-52^{8}$ & 76.0 & 5.5 & 1.11 & 4.4 & 2.6 & 0.083 & 0.20 & 1.02 & 1.11 & 8.08 & 100.10 & 13.82 & 31.33 & 7.9 \\
\hline $36-1,51-53$ & 46.4 & 12.2 & 3.18 & 11.5 & 7.1 & 0.226 & 0.36 & 1.70 & 1.06 & 14.43 & 98.16 & 3.80 & 31.42 & 20.5 \\
\hline $36-2,50-52$ & 59.1 & 14.9 & 3.85 & 1.2 & 8.9 & 0.459 & 0.42 & 2.05 & 1.21 & 7.03 & 99.12 & 3.97 & 19.39 & 2.1 \\
\hline $36-3,31-35$ & 59.2 & 13.8 & 3.59 & 1.3 & 9.7 & 2.89 & 0.38 & 2.00 & 1.42 & 6.66 & 100.94 & 4.29 & 3.36 & 2.3 \\
\hline $36-3,31-35^{\mathrm{h}}$ & 59.7 & 16.3 & 4.40 & 1.3 & 5.4 & 2.35 & 0.23 & 2.10 & 0.80 & 7.24 & 99.82 & 3.66 & 2.30 & 2.3 \\
\hline $36-3,31-35^{i}$ & 56.8 & 13.1 & 3.41 & 1.4 & 9.7 & 2.86 & 0.36 & 2.02 & 1.53 & 7.54 & 98.72 & 4.34 & 3.39 & 2.5 \\
\hline $36-3,50-52$ & 56.4 & 13.4 & 3.29 & 1.2 & 8.9 & 3.57 & 0.38 & 1.91 & 1.55 & 7.63 & 98.23 & 4.21 & 2.49 & 2.1 \\
\hline $36-3,70-72$ & 55.3 & 13.1 & 3.68 & 1.3 & 9.0 & 4.74 & 0.35 & 2.07 & 1.34 & 8.03 & 98.91 & 4.22 & 1.90 & 2.3 \\
\hline $36-3,82-85$. & 57.8 & 13.6 & 3.96 & 1.5 & 7.5 & 4.98 & 0.28 & 2.12 & 1.06 & 7.27 & 100.07 & 4.25 & 1.51 & 2.7 \\
\hline $36-3,82-85^{j}$ & 3.3 & 1.0 & 1.68 & 0.9 & 1.4 & 64.80 & 0.21 & 0.99 & 0.41 & 13.56 & 88.25 & 3.30 & 0.02 & 1.6 \\
\hline $36-3,82-85^{\mathrm{k}}$ & 1.8 & 0.8 & 1.06 & 0.6 & 0.5 & 68.2 & 0.19 & 0.70 & 0.29 & 14.80 & 88.94 & 2.25 & 0.01 & 1.1 \\
\hline $36-3,97-98$ & 77.8 & 8.6 & 1.35 & 0.5 & 3.4 & 0.113 & 0.36 & 1.49 & 1.95 & 4.48 & 100.04 & 9.05 & 30.09 & 0.9 \\
\hline $36-3,98-99$ & 27.9 & 6.7 & 1.49 & 30.9 & 4.8 & 0.643 & 0.26 & 0.93 & 0.66 & 26.79 & 100.97 & 4.15 & 7.47 & 55.2 \\
\hline $36-3,101-103$ & 19.8 & 4.6 & 0.92 & 36.6 & 3.4 & 0.523 & 0.20 & 0.74 & 0.42 & 31.79 & 98.99 & 4.30 & 6.50 & 65.3 \\
\hline $38-1,48-50$ & 21.0 & 3.7 & 0.93 & 38.6 & 1.5 & 0.461 & 0.13 & 0.49 & 0.09 & 32.15 & 99.05 & 5.68 & 3.25 & 68.9 \\
\hline
\end{tabular}

Note: Total $\mathrm{Fe}$ was calculated as $\mathrm{Fe}_{2} \mathrm{O}_{3}$ and total $\mathrm{Mn}$ as $\mathrm{Mn}_{3} \mathrm{O}_{4} ; \mathrm{CaCO}_{3}$ was calculated using the total $\mathrm{CaO}$.

a Sample nodule containing $0.30 \% \mathrm{P}_{2} \mathrm{O}_{5}$. g Indurated part.

b Crust fragments containing $1.02 \% \mathrm{BaO}$. h Pink fraction.

c Crust fragments containing $0.89 \% \mathrm{BaO}$. i Pale fraction.

d Pale fraction.

e Dark fraction containing $0.35 \% \mathrm{P}_{2} \mathrm{O}_{5}$.

j Sample of small nodule containing $7.95 \% \mathrm{BaO}$.

f Bioturbated zone.

of $\mathrm{Ba}$ are in the $\mathrm{Fe}-\mathrm{Mn}$ crusts from the volcanic-sedimentary level and in the small Mn nodules from the brown clays (Fig. 5) (about 0.7 and $11 \% \mathrm{BaO}$, respectively). According to the TEM investigations, which accurately show biogenic relics, the enrichment in $\mathrm{Ba}$ and $\mathrm{Sr}$ of Mn nodules results from the diagenetic evolution of accumulated siliceous organisms of the previous fecal pellets and of the surrounding and underlying sediments.

\section{Aluminum and Iron Relationships}

The simultaneous increase of $\mathrm{Al}$ and $\mathrm{Fe}$ contents in the marly chalk and mudstones corresponds to a similar increase in the clay minerals (Fig. 7). The brown clays are relatively enriched in iron, and samples of the crusts are rich in $\mathrm{Al}$, depending on their mineral assemblages. For example, prevalent smectites and oxides occur in the brown clays, and zeolites (also associated with higher
$\mathrm{K}$ and $\mathrm{Na}$ contents) occur in the volcanic-sedimentary section.

\section{Oxide Composition}

The various metalliferous concretions (crusts and nodules) are differentiated from each other by the $\mathrm{Mn}, \mathrm{Fe}$, and transitional element contents (Figs. 8 and 9 and Tables 1 and 2). The upper Eocene crusts are particularly enriched in $\mathrm{Ni}, \mathrm{Co}$, and $\mathrm{Ba}$ and lesser amounts of $\mathrm{Cu}$, $\mathrm{Zn}$, and $\mathrm{Zr}$. A large nodule found within the Oligocene deposits (Fig. 3) has a high content of trace elements, particularly $\mathrm{Zn}, \mathrm{V}$, and $\mathrm{Zr}$. By comparison, the small nodules from the Paleocene brown clays are depleted in $\mathrm{Ni}$ and $\mathrm{Co}$ but are enriched in $\mathrm{V}$ and $\mathrm{Cu}$, as are $\mathrm{Sr}$ and $\mathrm{Ba}$. The characteristics of the upper Eocene crust and the large nodule are intermediate between those of the deep sea nodules from the Pacific sediments and those 
Table 2. Bulk chemical analyses of sediments from Site 550 (in ppm).

\begin{tabular}{|c|c|c|c|c|c|c|c|c|c|}
\hline $\begin{array}{c}\text { Sample } \\
\text { (interval in } \mathrm{cm} \text { ) }\end{array}$ & Sr & $\mathrm{Ba}$ & v & $\mathrm{Ni}$ & Co & $\mathrm{Cr}$ & $\mathrm{Zn}$ & $\mathrm{Cu}$ & $\mathrm{Zr}$ \\
\hline $50-23-5,23-25$ & 1145 & 480 & 24 & 140 & 27 & 23 & 42 & 40 & 28 \\
\hline $23-5,104-105$ & 1045 & 1227 & 41 & 107 & 23 & 34 & 65 & 80 & 46 \\
\hline $23, \mathrm{CC}$ & 1095 & 774 & 25 & 86 & 16 & 27 & 58 & 71 & 31 \\
\hline $24-1,35-37$ & 1072 & 1270 & 56 & 144 & 35 & 31 & 98 & 115 & 66 \\
\hline $24-1,81-83$ & 1109 & 1699 & 60 & 124 & 46 & 35 & 90 & 80 & 64 \\
\hline $24-1,90-94$ & 1380 & 1863 & 54 & 102 & 30 & 32 & 77 & 73 & 56 \\
\hline $24-1,97-99$ & 1169 & 1580 & 51 & 104 & 35 & 33 & 78 & 70 & 65 \\
\hline $24-1,100-101^{a}$ & 646 & 1068 & 1036 & 3646 & 3757 & 39 & 431 & 2403 & 814 \\
\hline $24-2,20-22$ & 850 & 1561 & 86 & 135 & 47 & 48 & 126 & 100 & 81 \\
\hline $24-2,46-48^{b}$ & 610 & 6145 & 249 & 578 & 453 & 55 & 224 & 561 & 169 \\
\hline $24-2,50-52$ & 407 & 2680 & 143 & 304 & 158 & 88 & 170 & 340 & 159 \\
\hline $24-2,57-59$ & 520 & 800 & 111 & 229 & 66 & 78 & 157 & 230 & 139 \\
\hline $24-2,68-70$ & 426 & 1064 & 102 & 233 & 111 & 57 & 157 & 293 & 119 \\
\hline $24-2,70-71^{\mathrm{c}}$ & 677 & 6364 & 218 & 1835 & 1594 & 72 & 391 & 1165 & 154 \\
\hline $24-2,74-75$ & 574 & 1443 & 127 & 190 & 79 & 89 & 123 & 144 & 117 \\
\hline $24-2,74-75^{d}$ & 459 & 743 & 66 & 138 & 55 & 55 & 68 & 117 & 73 \\
\hline $24-2,74-75^{e}$ & 711 & 3462 & 200 & 1239 & 1421 & 79 & 182 & 397 & 120 \\
\hline $24-3,20-22$ & 799 & 725 & 85 & 101 & 32 & 58 & 99 & 93 & 77 \\
\hline $24-3,50-52$ & 620 & 1408 & 144 & 130 & 52 & 82 & 109 & 123 & 107 \\
\hline $24-4,20-22$ & 515 & 1053 & 118 & 117 & 35 & 71 & 225 & 145 & 93 \\
\hline $24-4,20-22^{f}$ & 583 & 440 & 87 & 115 & 22 & 69 & 102 & 110 & 83 \\
\hline $24-5,20-21$ & 585 & 231 & 82 & 102 & 21 & 67 & 101 & 133 & 84 \\
\hline $24-5,21-22$ & 584 & 1077 & 111 & 115 & 54 & 67 & 105 & 138 & 82 \\
\hline $28-1,40-42$ & 760 & 262 & 93 & 99 & 29 & 50 & 84 & 49 & 59 \\
\hline $32-1,50-52$ & 688 & 711 & 71 & 95 & 26 & 55 & 68 & 56 & 79 \\
\hline $34-1,50-52$ & 737 & 720 & 81 & 101 & 29 & 62 & 77 & 54 & 69 \\
\hline $35-1,50-52$ & 438 & 633 & 155 & 96 & 41 & 53 & 68 & 140 & 59 \\
\hline $35-1,50-52^{\mathrm{g}}$ & 195 & 589 & 79 & 40 & 28 & 38 & 39 & 31 & 53 \\
\hline $36-1,51-53$ & 547 & 768 & 86 & 93 & 33 & 56 & 90 & 51 & 70 \\
\hline $36-2,50-52$ & 361 & 861 & 142 & 90 & 35 & 61 & 100 & 199 & 78 \\
\hline $36-3,31-35$ & 440 & 946 & 75 & 120 & 76 & 58 & 109 & 446 & 102 \\
\hline $36-3,31-35^{\mathrm{h}}$ & 338 & 289 & 31 & 124 & 53 & 78 & 94 & 586 & 76 \\
\hline $36-3,31-35^{i}$ & 341 & 708 & 70 & 112 & 51 & 78 & 120 & 407 & 98 \\
\hline $36-3,50-52$ & 455 & 1429 & 79 & 112 & 56 & 61 & 119 & 391 & 91 \\
\hline $36-3,70-72$ & 434 & 1671 & 77 & 147 & 64 & 59 & 106 & 384 & 90 \\
\hline $36-3,82-85$ & 476 & 1620 & 84 & 138 & 95 & 52 & 104 & 352 & 93 \\
\hline $36-3,82-85$ & 4209 & 5 & 1034 & 172 & 697 & 163 & 86 & 1493 & 97 \\
\hline $36-3,82-85^{k}$ & 5540 & s & 1404 & 176 & 575 & 131 & 95 & 1261 & 122 \\
\hline $36-3,97-98$ & 420 & 156 & 93 & 66 & 23 & 63 & 63 & 92 & 78 \\
\hline $36-3,98-99$ & 673 & 94 & 40 & 87 & 37 & 31 & 56 & 102 & 55 \\
\hline $36-3,101-103$ & 790 & 76 & 34 & 86 & 23 & 27 & 51 & 57 & 38 \\
\hline $38-1,48-50$ & 783 & 273 & 40 & 88 & 33 & 26 & 47 & 24 & 24 \\
\hline
\end{tabular}

Note: Same legend as Table 1. $s=$ value over the upper detection limit.

of the crusts formed under volcanic influences (Hoffert, Karpoff, et al., 1978; Karpoff et al., 1980). From their trace-metal signatures the small Mn nodules from the Paleocene brown clays appear to lie in the "hydrothermal" field established by Bonatti et al. (1972), Hoffert, Perseil, et al. (1978), and Toth (1980). Nevertheless, as suggested by Toth (1980), their $\mathrm{Ba}$ and $\mathrm{Sr}$ concentrations do not corroborate the hydrothermal origin.

\section{Geochemical Composition of Authigenic Phases: Environmental Influences}

The partitioning of $\mathrm{Fe}, \mathrm{Mn}$, and trace elements into authigenic silicates and oxides has been studied by numerous authors. Burns and Burns $(1978,1979)$ propose several processes: (1) a reaction between palagonite, biogenic silica, and pelagic clay, forming phillipsite and smectites; and (2) a reaction between organic matter and amorphous $\mathrm{Fe}$ and $\mathrm{Mn}$ oxihydroxides forming todorokite and soluble iron. Lyle et al. (1977) have suggested that the presence of reactive silica promotes the formation of Fe-rich smectites and that Mn crystallizes as todorokite. The important contribution of siliceous organisms to the authigenesis of smectites and oxides has been recently shown by Hoffert (1980) and Marchig and Gundlach (1981). The bacteria and organic matter are sometimes involved in the Mn accumulation and in the relatively lower redox potential, making conditions more favorable to the formation of todorokite rather than $\delta$ $\mathrm{MnO}_{2}$ (Lynn and Bonatti, 1965; Cronan, 1975; Varentsov and Grasselly, 1980). The crystallization of Mn oxides and the mechanisms of uptake of trace elements have been analyzed by Burns (1976), Burns and Burns (1979), and Arrhenius et al. (1979).

Shallow-water nodules are mostly made up of todorokite and are usually poor in trace elements (Dunham and Glasby, 1974; Calvert and Price, 1977). The origin of enrichment of trace elements in interstitial water and seawater, and thus in sediments and concretions, has been debated in numerous works on deep-sea nodules and crusts as either volcanogenic (e.g., $\mathrm{Ni}, \mathrm{Co}$, and $\mathrm{Zr}$ ) or as biogenic (e.g., $\mathrm{Ba}, \mathrm{Sr}, \mathrm{Ni}, \mathrm{Cu}, \mathrm{Pb}$, and $\mathrm{V}$ ) (see additional references in Glasby, 1977; Hoffert, 1980).

The geochemical data on Site 550 samples, in agreement with the studies just cited, permit an accurate reconstruction of the sedimentary environment and the related early diagenetic environment of the deposits during two slow accumulation periods.

The depositional environment for the upper Paleocene brown clays was somewhat restricted and confined and was at medium depth $(\sim 3000 \mathrm{~m})$ (site chapter, this volume). It was suitable for the temporary preservation of organic matter and for the added action of bacteria on fecal pellets (Thompson and Whelan, 1980) that probably originated from the nearby continental margin (Fig. 2). The early diagenesis of the sediment under intermediate redox potential conditions induces formation of well-crystallized Mn oxide concretions, which also have high contents of $\mathrm{Ba}, \mathrm{Sr}$, and $\mathrm{V}$ released by the epigenetized biogenic sediments. The presence of active silica and $\mathrm{Fe}$ promotes the transformation and authigenesis of smectites, which are prevalent in this facies.

A sporadic, slightly confined environment during early deposition of the brown clays is in accordance with the restricted circulation that apparently prevailed earlier during the Cenomanian (site chapter, this volume). During middle-late Eocene time, the deposits are mostly volcaniclastic mixed with a small, but consistent, amount of terrigenous and biogenic sediments. Deposition of the condensed facies occurred during a period of many hiatuses, on a deeper seafloor than during late Paleocene, and in an open, oxidized environment. This facies is thus diagenetically indurated by authigenic clays, zeolites, and $\mathrm{Fe}-\mathrm{Mn}$ oxides with the diagenetic processes having developed in the water-sediment interface. The crusts in this facies are enriched in $\mathrm{Ni}, \mathrm{Co}$, and $\mathrm{Ba}$ related to the halmyrolysis of the volcaniclastic and biogenic components.

Within the overlying Oligocene mud, the nodule may have resulted from (1) the disaggregation of the indurated level; (2) reworking of fragments within the mud; or (3) nucleation and diagenetic formation of layered $\mathrm{Fe}-$ Mn oxides. This facies is similar to facies of the same age described from volcanic sediments found in the South and North Pacific (Hoffert, Karpoff et al., 1978; Karpoff et al., 1980). The occurrence of tuffaceous sedi- 
Table 3. Bulk chemical analyses of sediments from Site 550 (in wt.\%) recalculated on a CaO-free basis.

\begin{tabular}{|c|c|c|c|c|c|c|c|c|c|c|}
\hline $\begin{array}{c}\text { Sample } \\
\text { (interval in } \mathrm{cm} \text { ) }\end{array}$ & $\mathrm{SiO}_{2}$ & $\mathrm{Al}_{2} \mathrm{O}_{3}$ & $\mathrm{MgO}$ & $\mathrm{Fe}_{2} \mathrm{O}_{3}$ & $\mathrm{Mn}_{3} \mathrm{O}_{4}$ & $\mathrm{TiO}_{2}$ & $\mathrm{BaO}$ & $\mathrm{Na}_{2} \mathrm{O}$ & $\mathrm{K}_{2} \mathrm{O}$ & $\begin{array}{l}\text { LOI at } \\
1000^{\circ} \mathrm{C}\end{array}$ \\
\hline $550-23-5,23-25$ & 56.4 & 18.3 & 3.76 & 7.4 & 1.22 & 0.69 & 0.30 & 2.18 & 0.40 & 9.34 \\
\hline $23-5,104-105$ & 61.7 & 19.6 & 3.97 & 6.7 & 1.00 & 0.64 & 0.46 & 2.08 & 1.31 & 2.51 \\
\hline $23, \mathrm{CC}$ & 57.7 & 18.6 & 4.17 & 6.6 & 0.98 & 0.66 & 0.45 & 1.90 & 0.29 & 8.66 \\
\hline $24-1,35-37$ & 61.1 & 16.7 & 3.60 & 6.3 & 0.77 & 0.59 & 0.34 & 1.97 & 1.99 & 6.55 \\
\hline $24-1,81-83$ & 61.7 & 16.0 & 2.98 & 6.2 & 0.85 & 0.62 & 0.46 & 2.27 & 2.65 & 6.21 \\
\hline $24-1,90-94$ & 59.4 & 16.2 & 2.85 & 6.0 & 0.86 & 0.58 & 0.49 & 2.23 & 2.85 & 8.45 \\
\hline $24-1,97-99$ & 58.4 & 15.4 & 2.64 & 5.5 & 0.66 & 0.53 & 0.42 & 2.11 & 3.33 & 11.05 \\
\hline $24-1,100-101^{\mathrm{a}}$ & 34.7 & 3.4 & 1.33 & 27.7 & 12.22 & 0.60 & 0.12 & 1.15 & 0.81 & 17.89 \\
\hline $24-2,20-22$ & 60.2 & 16.5 & 3.56 & 7.6 & 0.88 & 0.63 & 0.31 & 2.07 & 3.22 & 5.06 \\
\hline $24-2,46-48^{b}$ & 55.4 & 15.5 & 3.14 & 6.6 & 6.28 & 0.41 & 1.02 & 2.20 & 2.63 & 6.84 \\
\hline $24-2,50-52$ & 58.6 & 16.3 & 2.83 & 7.7 & 1.13 & 0.53 & 0.31 & 2.31 & 3.65 & 6.57 \\
\hline $24-2,57-59$ & 60.5 & 17.3 & 2.71 & 6.1 & 0.55 & 0.54 & 0.09 & 2.31 & 3.80 & 6.05 \\
\hline $24-2,68-70$ & 59.7 & 17.3 & 2.57 & 5.6 & 0.94 & 0.49 & 0.12 & 2.92 & 4.02 & 6.34 \\
\hline $24-2,70-71^{\mathrm{c}}$ & 53.3 & 17.7 & 4.38 & 4.4 & 7.38 & 0.33 & 0.91 & 2.39 & 2.18 & 7.06 \\
\hline $24-2,74-75$ & 59.2 & 16.9 & 2.20 & 6.3 & 0.94 & 0.57 & 0.17 & 2.72 & 4.34 & 6.65 \\
\hline $24-2,74-75^{\mathrm{d}}$ & 59.3 & 16.8 & 1.54 & 3.4 & 0.46 & 0.27 & 0.08 & 4.08 & 5.42 & 8.58 \\
\hline $24-2,74-75^{\mathrm{e}}$ & 51.5 & 15.1 & 2.29 & 6.9 & 5.41 & 0.66 & 0.42 & 1.99 & 3.49 & 12.34 \\
\hline $24-3,20-22$ & 58.2 & 17.4 & 3.69 & 7.7 & 0.64 & 0.69 & 0.15 & 1.85 & 3.13 & 6.49 \\
\hline $24-3,50-52$ & 56.8 & 17.9 & 2.79 & 7.8 & 0.93 & 0.69 & 0.16 & 1.93 & 3.60 & 7.32 \\
\hline $24-4,20-22$ & 56.4 & 18.1 & 4.42 & 8.6 & 0.96 & 0.65 & 0.16 & 1.85 & 2.94 & 5.93 \\
\hline $24-4,20-22^{f}$ & 57.7 & 18.5 & 4.07 & 8.2 & 0.27 & 0.67 & 0.07 & 1.78 & 2.82 & 5.87 \\
\hline $24-5,20-21$ & 56.7 & 18.7 & 3.79 & 8.6 & 0.11 & 0.69 & 0.05 & 1.78 & 2.67 & 6.91 \\
\hline $24-5,21-22$ & 56.9 & 18.6 & 3.61 & 8.4 & 1.12 & 0.68 & 0.18 & 1.77 & 2.71 & 6.09 \\
\hline $28-1,40-42$ & 54.7 & 20.0 & 2.58 & 9.3 & 0.55 & 0.91 & 0.09 & 1.69 & 1.80 & 8.34 \\
\hline $32-1,50-52$ & 57.8 & 16.9 & 2.79 & 9.8 & 0.53 & 1.08 & 0.13 & 1.71 & 2.08 & 7.04 \\
\hline $34-1,50-52$ & 57.2 & 17.9 & 2.90 & 9.4 & 0.48 & 0.87 & 0.16 & 1.69 & 2.33 & 7.15 \\
\hline $35-1,50-52$ & 69.7 & 11.9 & 2.31 & 5.5 & 0.31 & 0.45 & 0.10 & 1.79 & 1.67 & 6.18 \\
\hline $35-1,50-52^{g}$ & 82.3 & 5.9 & 1.20 & 2.8 & 0.09 & 0.22 & 0.08 & 1.10 & 1.20 & 5.01 \\
\hline $36-1,51-53$ & 59.7 & 15.7 & 4.09 & 9.1 & 0.29 & 0.46 & 0.12 & 2.19 & 1.36 & 6.94 \\
\hline $36-2,50-52$ & 60.9 & 15.3 & 3.97 & 9.2 & 0.47 & 0.43 & 0.10 & 2.11 & 1.25 & 6.27 \\
\hline $36-3,31-35$ & 59.9 & 14.0 & 3.64 & 9.8 & 2.93 & 0.38 & 0.12 & 2.03 & 1.44 & 5.71 \\
\hline $36-3,31-35^{\mathrm{h}}$ & 61.2 & 16.7 & 4.51 & 5.5 & 2.41 & 0.24 & 0.04 & 2.15 & 0.82 & 6.38 \\
\hline $36-3,31-35^{\mathrm{i}}$ & 59.0 & 13.6 & 3.54 & 10.1 & 2.97 & 0.37 & 0.08 & 2.10 & 1.59 & 6.69 \\
\hline $36-3,50-52$ & 58.6 & 13.9 & 3.42 & 9.3 & 3.71 & 0.39 & 0.17 & 1.98 & 1.61 & 6.95 \\
\hline $36-3,70-72$ & 57.2 & 13.5 & 3.80 & 9.3 & 4.90 & 0.36 & 0.19 & 2.14 & 1.38 & 7.24 \\
\hline $36-3,82-85$. & 59.2 & 13.9 & 4.06 & 7.7 & 5.10 & 0.29 & 0.19 & 2.17 & 1.09 & 6.24 \\
\hline $36-3,82-85^{j}$ & 3.5 & 1.1 & 1.78 & 1.5 & 68.50 & 0.22 & 8.40 & 1.05 & 0.43 & 13.59 \\
\hline $36-3,82-85^{k}$ & 1.8 & 0.8 & 1.07 & 0.5 & 68.83 & 0.19 & 11.31 & 0.71 & 0.29 & 14.46 \\
\hline $36-3,97-98$ & 78.4 & 8.7 & 1.36 & 3.4 & 0.11 & 0.36 & 0.02 & 1.50 & 1.97 & 4.12 \\
\hline $36-3,98-99$ & 60.7 & 14.6 & 3.25 & 10.5 & 1.40 & 0.57 & 0.04 & 2.03 & 1.44 & 5.48 \\
\hline $36-3,101-103$ & 58.8 & 13.7 & 2.73 & 10.1 & 1.55 & 0.59 & 0.03 & 2.20 & 1.25 & 9.01 \\
\hline $38-1,48-50$ & 69.6 & 12.3 & 3.08 & 5.0 & 1.53 & 0.43 & 0.10 & 1.63 & 0.30 & 6.04 \\
\hline
\end{tabular}

Note: Same legend as Table 1.

ments indicating Eocene volcanism is fairly widespread in the northeastern Atlantic Ocean (Sites 398C, 403, and 404) (Renard et al., 1979; Harrison et al., 1979).

\section{SITE 548}

\section{Lithology}

Hole 548A was drilled at a shallow site on the Goban Spur (1256 m water depth) and penetrated $535 \mathrm{~m}$ of Quaternary to upper Campanian nannofossil ooze and chalk. Just above the Variscan basement (Lefort et al., this volume) a polymetallic incrusted chalk fragment was found.

The material available for this study includes (1) a thin section of a sample taken at the contact between the metalliferous concretion and the surrounding chalk and (2) small fragments of the crusts used for the geochemical analyses.

\section{Structure of the Concretion}

The sample found in the core catcher of Core 35 had a chalk layer on the top and a metalliferous crust at the bottom. If this orientation was that of the original deposit, the manganiferous crust may have formed between the chalk and the quartzitic basement. However, the sample may easily have been turned upside down by the drilling disturbance, and thus the concretion may have formed between two chalk layers. In the latter case, the contact with the Paleozoic quartzite would be unknown. In the following discussion, the sample is described with the Mn crust on top, as most marine crusts are.

The internal structure of the sample as seen in thin section displays several successive sedimentary and accretionary layers (Fig. 10). Chronology of the events of formation are as follows:

1. deposition of a micrite layer;

2. perforations on top of Layer 1;

3 and 4 . deposition of successive, highly oxidized, patchy micritic layers;

5. deposition of a thicker micrite layer of which some residual patches are preserved;

6. development of colloform diagenetic oxides within Layer 5 with columnar features forming botryoidal structures individually or laminae as groups; 


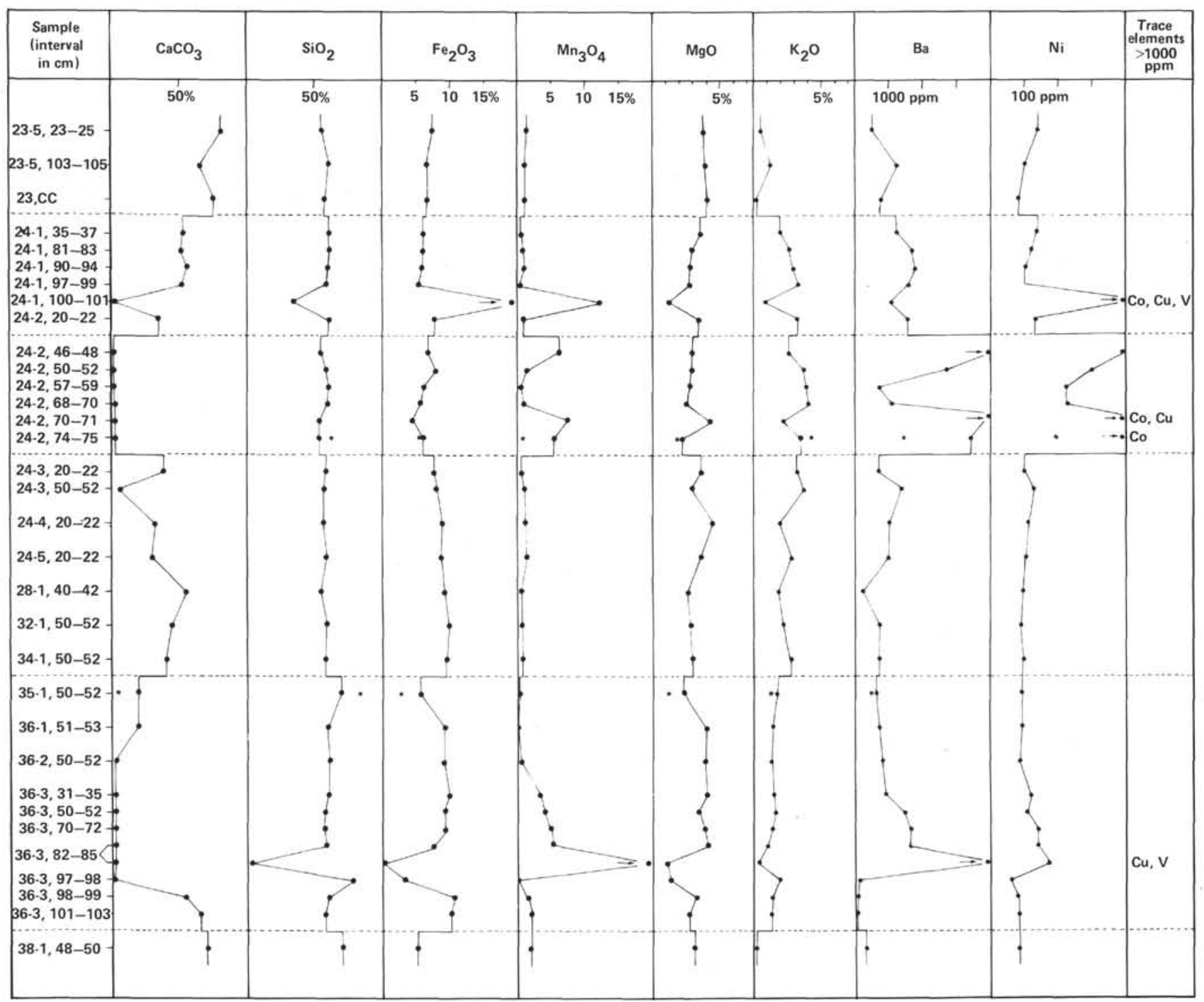

Figure 5. Schematic representation of chemical variations along the sedimentary column at Site 550 .

7. fracture of Layer 5, simultaneously with the accretion of columnar, colloform, and layered structures, related to the deformation by hydrostatic pressure;

8. deposition of new micrite containing small columnar-crust fragments filling the cracks; and

9. secondary accretion of manganiferous columns on the sides of the cracks.

Some subsequent mineralization took place in the porous material of Layer 1, as follows: (a) phosphatic compounds filled a perforation and columnar phosphatic deposits accreted outside the cavity; (b) similar textural features by Mn deposits developed in conjunction with centripetal diffusion; and (c) successive aureoles of wooly and pigmentary $\mathrm{Mn}$ colloforms and dendrites formed. Such internal features have been described by Sorem and Fewkes (1979) and Bourbon (1980).

\section{Chemical Composition}

Chemical data for Site 548, obtained in the same manner as for Site 550 samples, are given in Tables 4, 5, and 6. The data are from samples of five fragments of the outermost Mn crusts and Layer 1 micrite and of the underlying deposits $(36, \mathrm{CC})$ and the overlying chalk from Cores 34 and 35 .

The prevalent elements are $\mathrm{Ca}(45 \% \mathrm{CaO}), \mathrm{P}$ (mean of $23 \% \mathrm{P}_{2} \mathrm{O}_{5}$ ), and $\mathrm{Mn}$ (mean of $7 \% \mathrm{Mn}_{3} \mathrm{O}_{4}$ ). These contents are similar to those of shallow water and continental margin concretions (Tooms et al., 1969; Bourbon, 1980).

The ternary diagram of $\mathrm{Fe}$ versus $\mathrm{Mn}$ versus $\mathrm{Co}+\mathrm{Ni}$ $+\mathrm{Cu}$ (Fig. 11) gives an "hydrogenous" field for the available data close to that of the deep-sea nodules and upper Eocene crust from Site 550. This result seems to corroborate the diagenetic origin of the crust as previously discussed. A biogenic contribution during the accretion of $\mathrm{Fe}-\mathrm{Mn}$ oxides is supported by the high trace element content ( $\mathrm{Ba}, \mathrm{Ni}, \mathrm{Co}$, and $\mathrm{Zn})$.

\section{Environment of the Diagenetic Crust in Hole 548A}

The phosphatic composition of the studied crust corroborates a shallow paleodepth (estimated at 500 to $700 \mathrm{~m}$ ) for Site 548 during early Mesozoic time (Masson et al., 


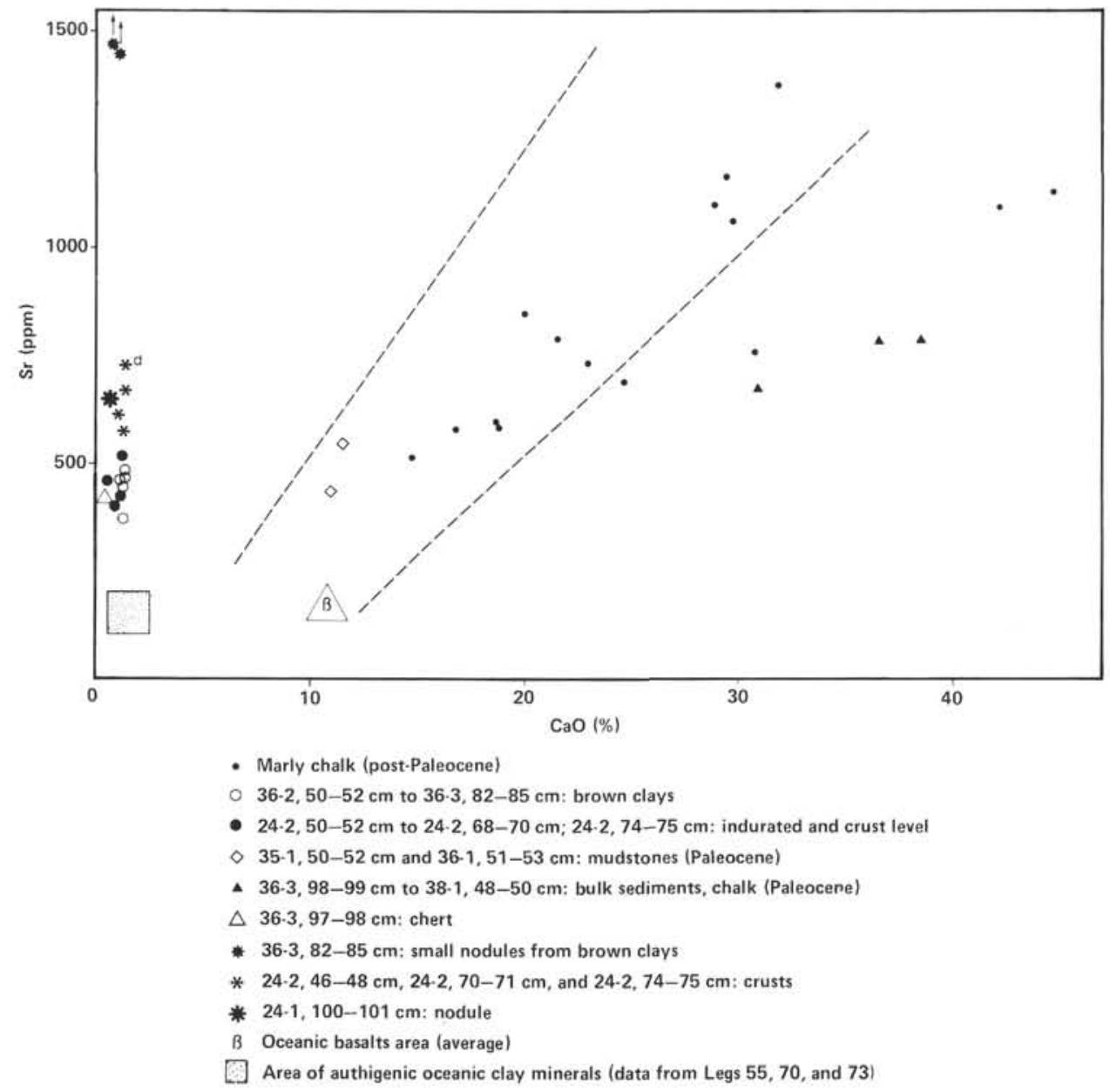

Figure 6. Relationships between $\mathrm{CaO}$ and $\mathrm{Sr}$ contents of bulk sediments at Site 550. Symbol superscripts as defined in Table 1 footnotes.

this volume). The distribution of phosphorites throughout the oceans through time has been reviewed by Arthur and Jenkyns (1981). The association of Mn and P authigenic crusts (Tooms et al., 1969) has also been observed in shallow water and volcanic environments (Karpoff et al., 1980) and in the North Atlantic by Schaaf et al. (1977).

The hiatus between the Variscan basement and the overlying Cretaceous chalk deposits was suitable for the diagenetic formation of the phosphatic and manganiferous crust on an older hard ground that had been established on a thin chalky deposit. The origin of the primary phosphatic and micritic encrustations is probably related to upwelling. The $\mathrm{Mn}$ in this case was apparently mostly from a continental source and was later deposited in an oxidized environment (Calvert and Price, 1977).

\section{CONCLUSIONS}

Cores from Sites 548 and 550 contain several encrusted sedimentary levels that permit us to reconstruct the varying depositional environments and the subsequent diagenetic processes.

At Site 548, located on the upper slope of the continental margin, a phosphatic and manganiferous crust was formed during a long hiatus before the deposition of Upper Cretaceous chalk on the Devonian basement.
The formation of such a phosphatic crust apparently resulted from upwelling and epicontinental influences in shallow warm water. The secondary diagenetic accretion of Mn oxides marks a slight change to a cooler and more oxidized marine environment.

This long hiatus during which formation of a thin phosphatic crust occurred seems to correspond to the Late Jurassic to earliest Cretaceous episode of the formation of "phosphorite giants" described by Arthur and Jenkyns (1981). Similar Vraconian-Cenomanian facies have also been observed in the Western Alps by Bourbon (1980).

At Site 550, two periods with low sedimentation rates promoted the formation of metalliferous enrichments. During late Paleocene time, a slightly reducing environment at intermediate depth (about $3000 \mathrm{~m}$ ) was suitable for the temporary preservation of organic-carbon-rich fecal pellets. They were subsequently replaced by wellcrystallized manganate exceptionally rich in $\mathrm{Ba}$. Other diagenetic features include (1) the formation of smectite and Fe oxides in the surrounding "red clays" and (2) the formation of cristobalite and silicates (clays and zeolites) at the top and bottom of the section.

In the North Atlantic during late Paleocene time the major paleoceanographic event was the separation of Greenland from Iceland and the subsequent modifica- 


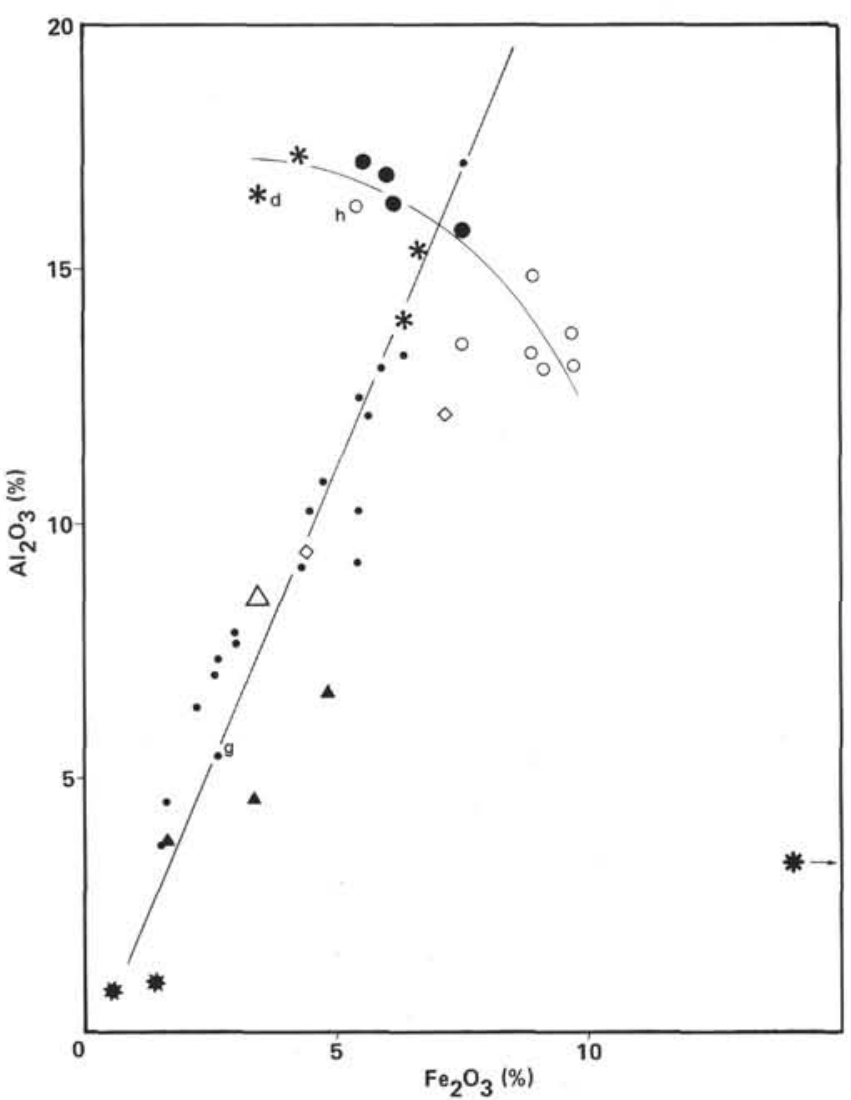

Figure 7. Relationship between $\mathrm{Al}_{2} \mathrm{O}_{3}$ and $\mathrm{Fe}_{2} \mathrm{O}_{3}$ contents of bulk sediments at Site 550. Same symbols as in Figure 6 and symbol superscripts as in Table 1.

tion of oceanic circulation caused by warm surface water from the south mixing with cold bottom water from the north (reference in Haq, 1981). This layering of water masses could explain the preservation of detrital organic compounds during their fall through the water column and their subsequent diagenetic alteration within the sediment by more corrosive interstitial waters.

During middle and late Eocene time, a condensed volcanic-sedimentary section was deposited and underwent early diagenesis via authigenesis to clays, zeolites, and coatings of Ni-rich Fe-Mn oxides. The mineralogy and geochemistry suggest a cooler, more oxidized environment in water deeper than during late Paleocene time.

The volcanic contribution in the North Atlantic deposits during middle to late Eocene time has been described by Renard et al. (1979), Harrison et al. (1979), and Knox (this volume). As established by numerous authors (cited in Haq, 1981), the volcanic compounds are apparently related to the activity of Iceland and the Reykjanes Province during the late Eocene. At the same time the colder bottom-water circulation (overflow from the Norwegian bottom water above the Faroe Ridge) was strengthened. This Eocene to early Oligocene cooling event has been well documented by oxygen isotope data.

The common factor of these three condensed facies is the very low sedimentation rate which allowed environmental influences (organic, oxidizing, and volcanic vs. continental) to form differentiated authigenic phases and specific metal-enriched manganiferous levels.

\section{ACKNOWLEDGMENTS}

The analytical work was performed with the technical support of the Centre de Sédimentologie et Géochimie de la Surface of the CNRS and of the Institut de Géologie, Strasbourg. We are especially grateful to G. Ehret and H. Bari for the TEM and SEM investigations. We particularly thank P. Gauer and M. Gruner for their technical participation. This article has benefited from the review of $\mathrm{H}$. C. Jenkyns and R. W. O'B. Knox.

\section{REFERENCES}

Arrhenius, G. O., 1963. Pelagic sediments. In Hill, M. N. (Ed.), The Sea (Vol. III): New York (Interscience), pp. 655-727.

Arrhenius, G. O., Cheung, K., Crane, S., et al., 1979. Counterions in marine manganates. La Genèse des Nodules de Manganèse, Coll. Int. CNRS, 289:333-356.

Arrhenius, G. O., and Tsai, A. G., 1981. Structure, phase transformation and prebiotic catalysis in marine manganate minerals. S.I.O. Ref. Ser., 28:1-19.

Arthur, M. A., and Jenkyns, H. C., 1981. Phosphorites and paleoceanography. Oceanol. Acta Proc., 26th Int. Geol. Congr., Paris 1980 , pp. 83-86.

Besnus, Y., and Rouault, R., 1973. Une méthode d'analyse des roches au spectromètre d'arc à lecture directe par un dispositif d'électrode rotative. Analusis, 2:111-116.

Bonatti, E., 1972. Marine authigenesis of minerals. In Fairbridge, R. W. (Ed.), Encycl. Geochem. Environ. Sci., IVA: pp. 48-56.

Bonatti, E., Kraemer, T., and Rydell, H. S., 1972. Classification and genesis of submarine iron-manganese deposits. Ferromanganese Deposits on the Ocean Floor: Palisades, N. Y. (Lamont-Doherty Geol. Observ. Columbia Univ.), pp. 149-166.

Boström, K., Lysen, L., and Moore, C., 1978. Biological matter as a source of authigenic matter in pelagic sediments. Chem. Geol., 23: 11-20.

Bourbon, M., 1980. Évolution d'un secteur de la marge nord-téthysienne en milieu pélagique: la zone briançonnaise près de Briançon entre le début du Malm et l'Eocène inférieur [Thèse doct.]. Université Louis Pasteur, Strasbourg.

Burns, R. G., 1976. The uptake of cobalt into ferromanganese nodules, soils and synthetic manganese (IV) oxides. Geochim. Cosmochim. Acta, 40:95-102.

Burns, V. M., and Burns, R. G., 1978. Post depositional metal enrichment processes inside manganese nodules from the north Equatorial Pacific. Earth Planet. Sci. Lett., 39:341-348.

1979. Observations of processes leading to the uptake of transition metals in manganese nodules. La Genèse des Nodules de Manganèse. Coll. Int. CNRS, 289:385-404.

Burton, J. D., 1966. Some problems concerning the marine geochemistry of barium. Nature, 212:976-978.

Calvert, S. E., and Price, N. B., 1977. Shallow water, continental margin and lacustrine nodules: distribution and geochemistry. In Glasby, G. P. (Ed.), Marine Manganese Deposits: Elsevier Oceanog. Ser. Amsterdam, 15:45-86.

Chamley, H., Debrabant, P., Foulon, J., d'Argoud, G. G., Latouche, C., et al., 1979. Mineralogy and geochemistry of Cretaceous and Cenozoic Atlantic sediments off the Iberian Peninsula (Site 398, DSDP Leg 47B). In Sibuet, J. C., Ryan, W. B. F., et al., Init. Repts. DSDP, 47, Pt. 2: Washington (U.S. Govt. Printing Office), 429-449.

Chukhrov, F. V., Gorshkov, A. I., Rudnitskaya, E. S., Beresovskaya, V. V., and Sivtsov, A. V., 1980. Manganese minerals in clays: a review. Clays Clay Miner., 28:346-354.

Church, T. M., and Velde, B., 1979. Geochemistry and origin of a deep-sea Pacific palygorskite deposit. Chem. Geol., 25:31-39.

Couture, R. A., 1977. Composition and origin of palygorskite-rich and montmorillonite-rich zeolite containing sediments from the $\mathrm{Pa}$ cific Ocean. Chem. Geol, 19:113-130.

Cronan, D. S., 1975. Geological and geochemical factors determining the variability of marine manganese nodules. Oceanol. Int., $75: 118-120$. 
Debrabant, P., Chamley, H., Foulon, J., and Maillot, H., 1979. Mineralogy and geochemistry of Upper Cretaceous and Cenozoic sediments from North Biscay Bay and Rockall Plateau (eastern North Atlantic), DSDP Leg 48. In Montadert, L., Roberts, D. G., et al., Init. Repts. DSDP, 48: Washington (U.S. Govt. Printing Office), 703-722.

Donnelly, T. W., and Merrill, L., 1977. The scavenging of magnesium and other chemical species by biogenic opal in deep-sea sediments. Chem. Geol., 19:167-186.

Dunham, A. C., and Glasby, G. D., 1974. Petrographic and electron microprobe investigations of some deep- and shallow-water manganese nodules. N.Z. J. Geol. Geophys., 17(4):929-953.

Friedrich, G. H., 1976. Manganese micronodules in deep-sea sediments and their relation to manganese nodule fields. Tech. Bull. U.N. Econ. Soc. Comm. Asia Pac. Comm. Coord. J. Prospect. Miner. Resour. South Pac. Offshore Areas, 2:39-53.

Glasby, G. P., 1977. Marine manganese deposits. Elsevier Oceanogr. Ser. Amsterdam, 15:523.

Gurwich, Y. G., Dogdanov, Y. A., and Lisitzyn, A. P., 1978. Behavior of barium in recent sedimentation in the Pacific. Geochem. Int., $15(2): 28-44$.

Haq, B. U., 1981. Paleogene paleoceanography: Early Cenozoic oceans revisited. Oceanol. Acta Proc. 26th Int. Geol. Congr., Paris 1980, pp. 71-82.

Harrison, R. K., Knox, R. W. O'B., and Morton, A. C., 1979. Petrography and mineralogy of volcanogenic sediments from DSDP Leg 48, southwest Rockall Plateau, Sites 403 and 404. In Montadert, L., Roberts, D. G., et al., Init. Repts. DSDP, 48: Washington (U.S. Govt. Printing Office), 771-786.

Hataway, J., and Sachs, P., 1965. Sepiolite and clinoptilolite from the Mid-Atlantic Ridge. Am. Mineral., 50:852-867.

Hein, J. R., and Scholl, D. W., 1978. Diagenesis and distribution of late Cenozoic volcanic sediment in the Southern Bering Sea. Geol. Soc. Am. Bull., 89:197-210.

Hoffert, M., 1980. Les "Argiles Rouges des Grands Fonds" dans le Pacifique Centre-Est. Authigenèse, transport, diagenèse. Sci. Geol. Mem., 61:231.

Hoffert, M., Karpoff, A. M., Clauer, N., et al., 1978. Néoformation et altération dans trois faciès volcanosédimentaires du Pacifique Sud. Oceanol. Acta, 1-2:187-202.

Hoffert, M., Perseil, A., et al., 1978. Hydrothermal deposits sampled by diving saucer in Transform Fault " $\mathrm{A}$ " near $37^{\circ} \mathrm{N}$ on the Mid-Atlantic Ridge, FAMOUS area. Oceanol. Acta, 1:73-86.

Honnorez, J., 1978. Generation of phillipsite by palagonitization of basaltic glass in sea water and the origin of K-rich deep-sea sediments. In Sand, L. B., and Mumpton, F. A. (Eds.), Natural Zeolites: New York (Pergamon Press), pp. 245-258.

Iijima, A., Matsumoto, R., and Tada, R., 1980. Zeolite and silica diagenesis and sandstone petrography at Sites 438 and 439 off Sanri$\mathrm{ku}$, northwest Pacific, Leg 57, Deep Sea Drilling Project. In Scientific Party, Init. Repts. DSDP, 56, 57, Pt. 2: Washington (U.S. Govt. Printing Office), 1143-1158.

Jeans, C. V., 1978. Silicifications and associated clay assemblages in the Cretaceous marine sediments of Southern England. Clays Clay Miner., 13:101-126.

Karpoff, A. M., 1980. The sedimentary deposits of Suiko Seamount (Leg 55, Site 433): from the reef environment to the pelagic sedimentation. In Jackson, E. D., Koizumi, I., et al., Init. Repts. DSDP, 55: Washington (U.S. Govt. Printing Office), 491-501. 1984. Miocene red clays of the South Atlantic: dissolution facies of calcareous oozes at Deep Sea Drilling Project Sites 519 to 523, Leg 73. In Hsü, K. J., LaBrecque, J. L., et al., Init. Repts. DSDP, 73: Washington (U.S. Govt. Printing Office), 515-536.

Karpoff, A. M., Hoffert, M., and Clauer, N., 1981. Sedimentary sequences at Deep Sea Drilling Project Site 464: silicification processes and transition between siliceous biogenic oozes and brown clays. In Thiede, J., Vallier, T. L., et al., Init. Repts. DSDP, 62: Washington (U.S. Govt. Printing Office), 759-771.

Karpoff, A. M., Peterschmitt, I., and Hoffert, M., 1980. Mineralogy and geochemistry of sedimentary deposits on Emperor Seamounts, Site 430, 431, 432: authigenesis of silicates, phosphates, and ferromanganese oxides. In Jackson, E. D., Koizumi, I., et al., Init. Repts. DSDP, 55: Washington (U.S. Govt. Printing Office), 463-489.
Kastner, M., Keene, J. B., and Gieskes, J. M., 1977. Diagenesis of siliceous oozes-I. Chemical controls on the rates of opal-A to opalCT transformation, an experimental study. Geochim. Cosmochim. Acta, 41:1041-1059.

Kastner, M., and Stonecipher, S. A., 1978. Zeolites in pelagic sediments of Atlantic, Pacific and Indian Oceans. In Sand, L. B., and Mumpton, F. A. (Eds.), Natural Zeolites: New York (Pergamon Press), pp. 199-220.

Klasik, J. A., 1975. High cristobalite and high tridymite in a middle Eocene deep-sea chert. Science, 89:631-632.

Kohyama, N., and Sudo, T., 1975. Hisingerite occurring as a weathering product of iron-rich saponite. Clays Clay Miner., 23:215-218.

Lancelot, Y., 1973. Chert and silica diagenesis in sediments from the Central Pacific. In Winterer, E. L., Ewing, J. I., et al., Init. Repts. DSDP, 17: Washington (U.S. Govt. Printing Office), 337-405.

Latouche, C., and Maillet, N., 1979. X-ray mineralogy studies, Leg 48-Rockall region (Sites 403, 404, 405, and 406). In Montadert, L., Roberts, D. G., et al., Init. Repts. DSDP, 48: Washington (U.S. Govt. Printing Office), 665-676.

Latouche, C., Maillet, N., and Bonté, P., 1979. Relations entre les caractéristiques minéralogiques des sédiments et des dépôts polymétalliques entre la zone de fracture Kane et le Grand Météor. La Genèse des Nodules de Manganèse, Coll. Int. CNRS, 289:139-150.

Louail, J., 1979. Origine et significations des zéolites dans les dépôts* cénomaniens de la bordure Sud-Est du Massif Armoricain. Clays Clay Miner., 14:67-85.

Lyle, M., Dymond, T., and Heath, G. R., 1977. Copper-nickel-enriched ferromanganese nodules and associated crusts from the Bauer Basin, Northwest Nazca Plate. Earth Planet. Sci. Lett., 35: $55-64$

Lynn, D. C., and Bonatti, E., 1965. Mobility of manganese in diagenesis of deep sea sediments. Mar. Geol., 3:457-474.

Marchig, V., and Gundlach, H., 1981. Separation of iron from manganese and growth of manganese nodules as a consequence of diagenetic aging of radiolarians. Mar. Geol., 40:M34-M43.

Margolis, S. V., Dugolinsky, B. K., and Dudley, W. C., 1979. Microchemistry and morphology of biogenic detrital and authigenic phases in Pacific manganese nodules. La Genèse des Nodules de Manganèse, Coll. Int. CNRS, 289:179-209.

Moncure, G. K., Surdam, R. C., and McKague, H. L., 1981. Zeolite diagenesis below Pahute Mesa, Nevada Test Site. Clays Clay Miner., 29:385-396.

Moore, W. S., Ku, T. L., MacDougall, J. D., et al., 1981. Fluxes of metals to a manganese nodule: radiochemical, chemical, structural and mineralogical studies. Earth Planet. Sci. Lett., 52:151-171.

Morgenstein, M., 1967. Authigenic cementation of scoriaceous deepsea sediments west of the Society Ridge, South Pacific. Sedimentology, 9:105-118.

Nathan, Y., and Flexer, A., 1977. Clinoptilolite, paragenesis and stratigraphy. Sedimentology, 24:845-855.

Peterson, M. N. A., and von der Borch, C. C., 1965. Chert-modern inorganic deposition in a carbonate precipitating locality. Science, 149:1501-1503.

Petzing, J., and Chester, R., 1979. Authigenic marine zeolites and their relationship to global volcanism. Mar. Geol., 29:253-271.

Renard, M., Létolle, R., and Richebois, G., 1979. Some trace elements and their relation to oxygen and carbon isotopes in the carbonate samples recovered from Hole 400A of DSDP Leg 48. In Montadert, L., Roberts, D. G., et al., Init. Repts. DSDP, 48: Washington (U.S. Govt. Printing Office), 727-739.

Riech, V., 1979. Diagenesis of silica, zeolites, and phyllosilicates at Sites 397 and 398. In von Rad, U., Ryan, W. B. F., et al., Init. Repts. DSDP, 47, Pt. 1: Washington (U.S. Govt. Printing Office), 741-759.

Schaaf, A., Hoffert, M., Karpoff, A. M., and Wirrmann, D., 1977. Association de structures stromatolithiques et de foraminiferres sessiles dans un encroûtement ferromanganésifères à coeur granitique en provenance de l'Atlantique Nord. C. R. Acad. Sci. Paris, 284D: $1705-1708$.

Schwertmann, U., and Taylor, R. M., 1977. Iron oxides. In Dixon, J. B., and Weed, S. B. (Eds.), Mineral in Soils Environments: Madison (Soil. Sci. Soc. Am. Pub.), pp. 145-180. 1979. Natural and synthetic poorly crystallized lepidocrocite. Clays Clay Miner., 14(4):185-194. 
Singer, A., 1979. Palygorskite in sediments: detrital, diagenetic or neoformed. A critical review. Geol. Rundsch., 68(3):996-1008.

Sorem, R. K., and Fewkes, R. H., 1977. Internal characteristics. In Glasby, G. P. (Ed.), Marine Manganese Deposits: New York (Elsevier), pp. 147-184.

Taylor, M. W., and Surdam, R. C., 1981. Zeolite reactions in the tuffaceous sediments at Teels Marsh, Nevada. Clays Clay Miner., 29(5):341-352.

Thompson, P. R., and Whelan, J. K., 1980. Fecal pellets at Deep Sea Drilling Project Site 436. In Scientific Party, Init. Repts. DSDP, 56, 57, Pt. 2, Washington (U.S. Govt. Printing Office), 921-935.

Tooms, J. S., Summerhayes, C. P., and Cronan, D. S., 1969. Geochemistry of marine phosphorites and manganese deposits. Oceanogr. Mar. Biol., 7:49-100.

Toth, J. R., 1980. Deposition of submarine crusts in manganese and iron. Geol. Soc. Am. Bull., 91:44-54.

Trauth, D., Ehret, G., Eberhart, J. P., and Weber, F., 1977. Microscopie électronique et minéraux argileux: résultats obtenus et orientations actuelles. Notes Tech. Inst. Geol. Univ. Louis Pasteur Strasbourg, 7:16.
Turekian, K. K., 1964. The marine geochemistry of strontium. Geochim. Cosmochim. Acta, 28:1479-1496.

Turekian, K. K., and Tausch, E. H., 1964. Barium in deep-sea sediments of the Atlantic Ocean. Nature, 201:696-697.

Varentsov, I. M., and Grasselly, G., 1980. Manganese on the Bottom of Recent Basins. Geology and Geochemistry of Manganese (Vol. 3): Stuttgart (E. Schweizerbart'sche Verlagsbuchhandlung).

von Rad, U., 1979. $\mathrm{SiO}_{2}$-diagenesis in Tiefseesedimenten. Geol. Rundsch., 68:1025-1036.

Weber, F., and Larqué, P., 1978. Technique de préparation des minéraux argileux en vue de l'analyse par diffraction des rayons $\mathrm{X}$ Notes Tech. Inst. Geol. Univ. Louis Pasteur Strasbourg.

Wise, S. W., Jr., and Weaver, F. M., 1974. Chertification of ocean sediments. Spec. Pub. Int. Assoc. Sedimentol., 1:301-326.

Date of Initial Receipt: February 11, 1983

Date of Acceptance: May 5, 1983

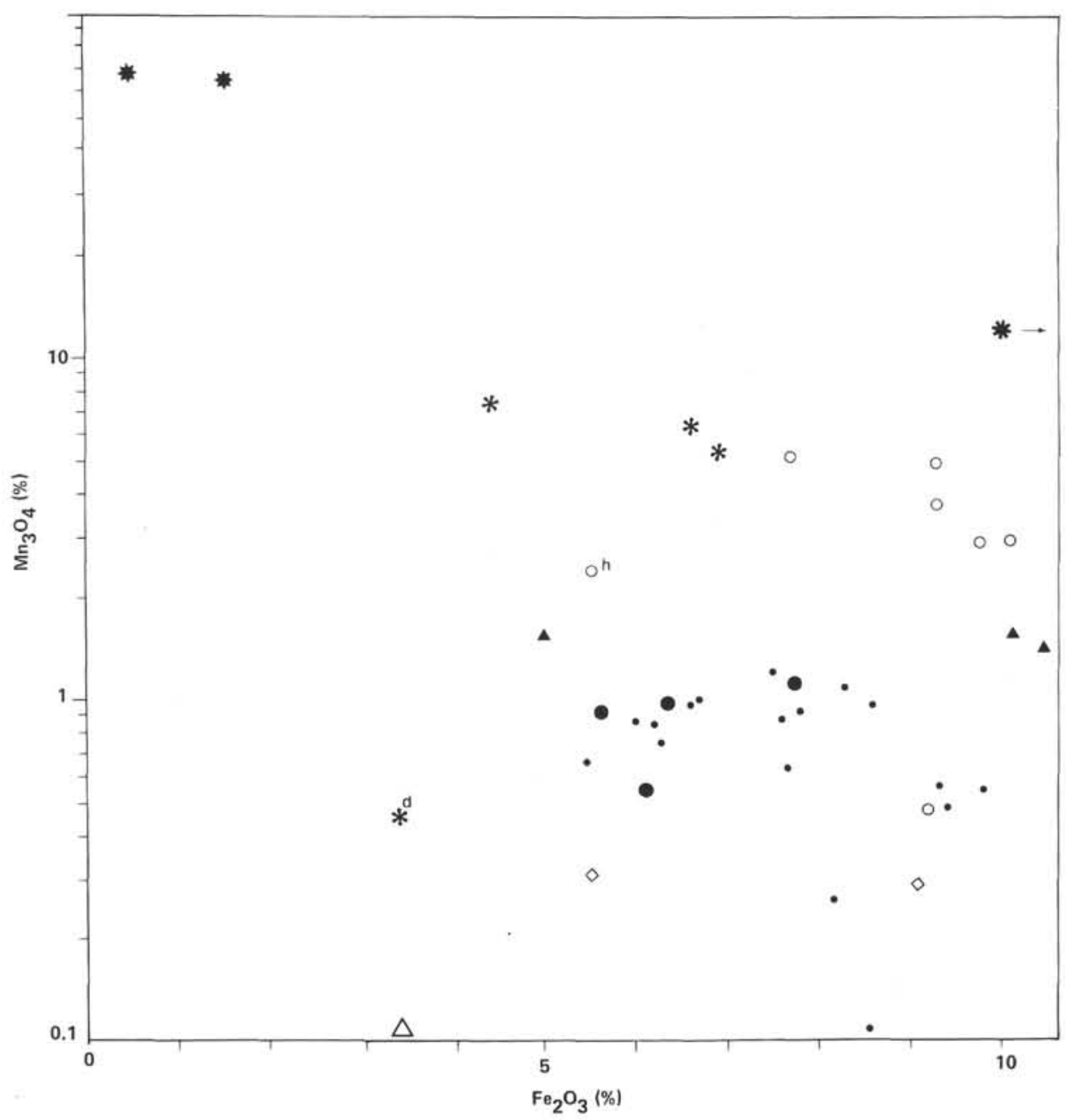

Figure 8. Relationship between $\mathrm{Mn}_{3} \mathrm{O}_{4}$ and $\mathrm{Fe}_{2} \mathrm{O}_{3}$ contents of bulk sediments at Site 550 (values on a CaOfree basis). Same symbols as in Figure 6 and symbol superscripts as in Table 1. 

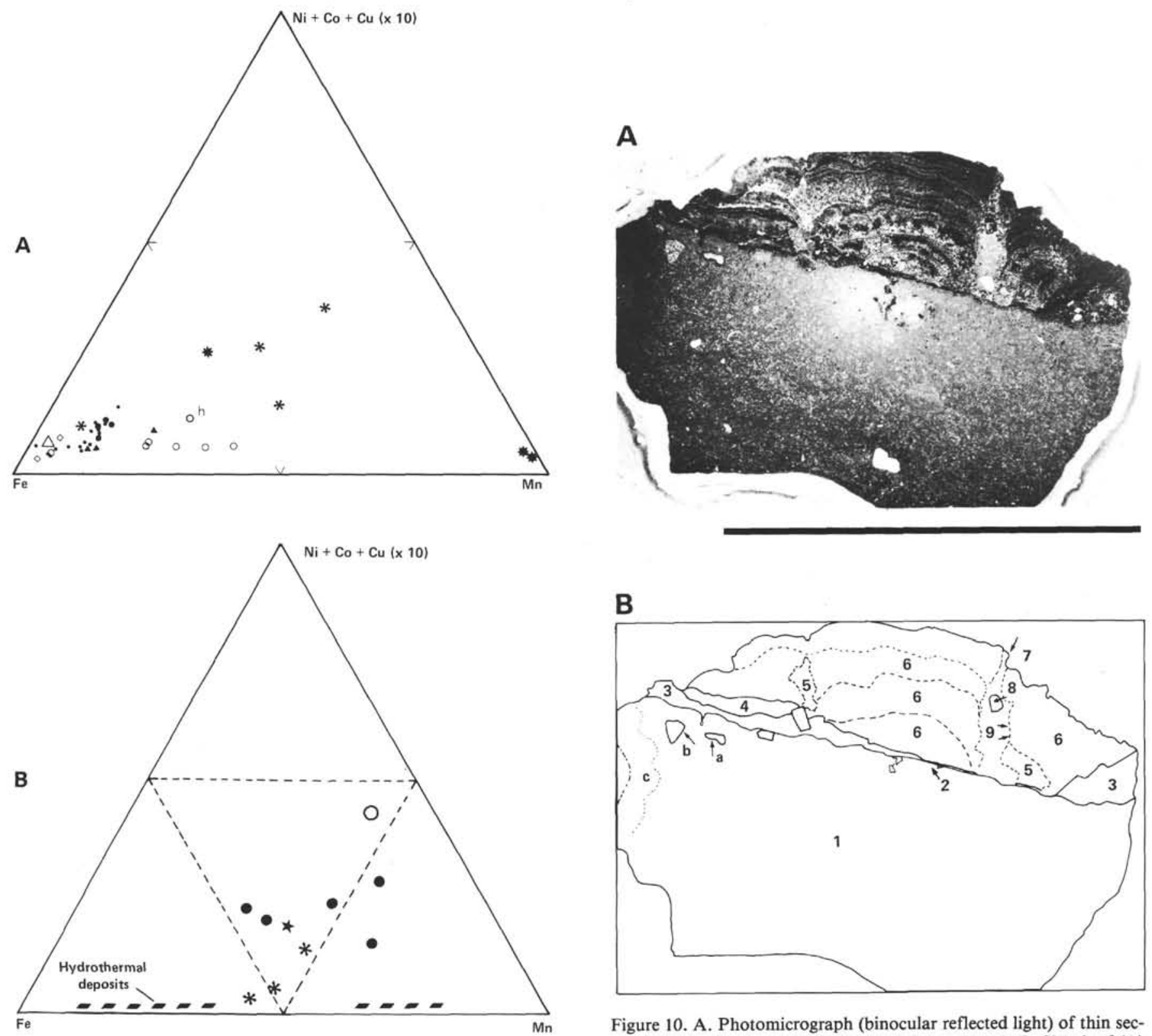

B

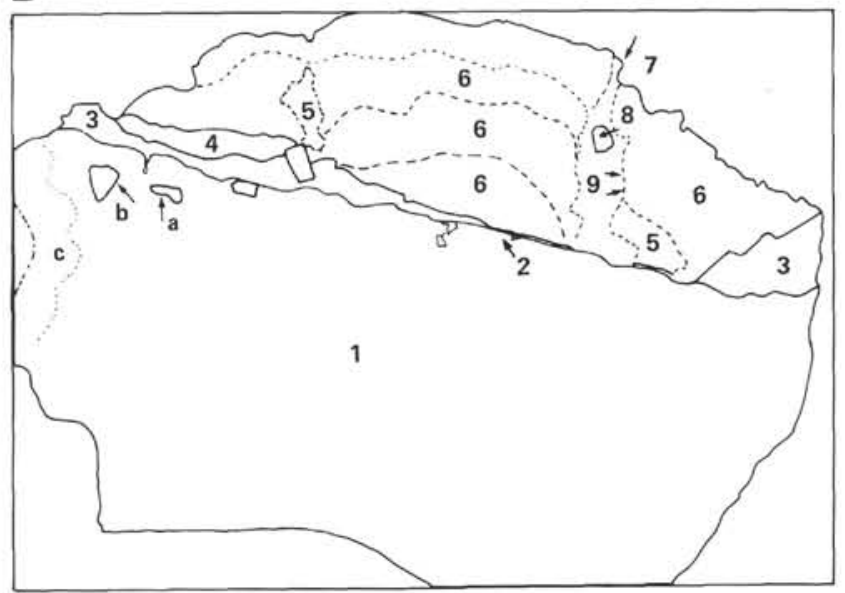

Figure 10. A. Photomicrograph (binocular reflected light) of thin section from Section 548-35, CC (scale bar $=4 \mathrm{~cm}$ ). B. Sketch of (A) showing the relationships of successive $\mathrm{Mn}$ and calcareous layers on the micrite layers. Numbers and letters are explained in text. ti et al. (1972) showing plots of Site 550 samples. Same symbols as in Figure 6 and symbol superscripts as in Table 1. B. Reference ternary diagram. * Seamounts and Timor nodules (Margolis et al., 1978); O Average for East Equatorial nodules; $\star$ Nodule from South Pacific (Hoffert, Karpoff, et al., 1978); Crusts from Emperor Seamounts (Karpoff et al., 1980). Hydrothermal deposits are from FAMOUS area (Hoffert, Perseil, et al., 1978). 
Table 4. Bulk chemical analyses of sediments from Site 548 (in wt.\%)

\begin{tabular}{|c|c|c|c|c|c|c|c|c|c|c|c|c|c|c|c|c|}
\hline $\begin{array}{c}\text { Sample } \\
\text { (interval in cm) }\end{array}$ & $\mathrm{SiO}_{2}$ & $\mathrm{Al}_{2} \mathrm{O}_{3}$ & $\mathrm{MgO}$ & $\mathrm{CaO}$ & $\mathrm{Fe}_{2} \mathrm{O}_{3}$ & $\mathrm{Mn}_{3} \mathrm{O}_{4}$ & $\mathrm{TiO}_{2}$ & $\mathrm{BaO}$ & $\mathrm{Na}_{2} \mathrm{O}$ & $\mathrm{P}_{2} \mathrm{O}_{5}$ & $\begin{array}{l}\mathrm{LO} \text { at } \\
1000^{\circ} \mathrm{C}\end{array}$ & Total & $\mathrm{Si} / \mathrm{Al}$ & $\mathrm{Fe} / \mathrm{Mn}$ & Apatite & Calcite \\
\hline $548-34-4,50-52$ & 2.2 & 0.7 & 0.27 & 53.3 & 0.3 & 0.089 & 0.04 & 0.02 & 0.18 & $s$ & 42.87 & 99.96 & 3.14 & 3.37 & 0 & 95.2 \\
\hline $35-2,6-8$ & 1.2 & 0.3 & 0.26 & 54.6 & 0.2 & 0.094 & 0.02 & 0.01 & 0.13 & s & 43.16 & 99.97 & 4.00 & 2.13 & 0 & 97.5 \\
\hline $35, \mathrm{CC}^{\mathrm{a}}$ & 1.8 & 1.3 & 0.92 & 44.6 & 2.0 & 5.47 & 0.07 & 0.08 & 0.41 & 22.7 & 13.59 & 94.94 & 1.38 & 0.37 & 53.6 & 30.1 \\
\hline $35, \mathrm{CC}^{\mathrm{a}}$ & 1.2 & 1.8 & 1.50 & 43.1 & 3.4 & 8.80 & 0.08 & 0.23 & 0.30 & 22.5 & 11.94 & 94.85 & 0.67 & 0.39 & 53.1 & 24.3 \\
\hline $35, \mathrm{CC}^{\mathrm{a}}$ & 3.1 & 1.4 & 2.30 & 43.9 & 3.0 & 6.43 & 0.09 & 0.10 & 0.23 & 24.0 & 11.55 & 96.10 & 2.21 & 0.47 & 56.6 & 22.3 \\
\hline $35, \mathrm{CC}^{\mathrm{a}}$ & 2.2 & 0.8 & 0.71 & 47.6 & 5.5 & 5.66 & 0.05 & 0.37 & 0.07 & 1.5 & 34.16 & 98.62 & 2.75 & 0.97 & 3.5 & 77.6 \\
\hline $35, \mathrm{CC}^{\mathrm{b}}$ & 1.2 & 0.4 & 0.24 & 53.7 & 0.2 & 0.073 & 0.03 & 0.01 & 0.15 & s & 43.31 & 99.31 & 3.00 & 2.74 & 0 & 95.9 \\
\hline $36, \mathrm{CC}$ & 5.3 & 1.2 & 0.63 & 49.9 & 1.5 & 0.060 & 0.05 & 0.05 & 0.65 & 16.6 & 21.42 & 97.36 & 4.42 & 2.50 & 39.2 & 48.7 \\
\hline
\end{tabular}

Note: Total Fe was calculated as $\mathrm{Fe}_{2} \mathrm{O}_{3}$ and total $\mathrm{Mn}$ as $\mathrm{Mn}_{3} \mathrm{O}_{4}, \mathrm{~K}_{2} \mathrm{O} \%$ was below lower detection limit. $\mathrm{s}=$ value below detection limit. Apatite is calculated with total $\mathrm{P}_{2} \mathrm{O}_{5} \%$ (with formula $\mathrm{Ca}\left(\mathrm{PO}_{4}\right)_{3} \mathrm{OH}$ ). Calcite is calculated with residual $\mathrm{CaO} \%$ and $\mathrm{LOI}$

b Hard white bottom part.

Table 5. Bulk chemical analyses of sediments from Site 548 (in ppm).

\begin{tabular}{lrrrrrrrrr}
\hline $\begin{array}{l}\text { Sample } \\
\text { (interval in cm) }\end{array}$ & \multicolumn{1}{c}{$\mathrm{Sr}$} & \multicolumn{1}{c}{$\mathrm{Ba}$} & \multicolumn{1}{c}{$\mathrm{V}$} & $\mathrm{Ni}$ & $\mathrm{Co}$ & $\mathrm{Cr}$ & $\mathrm{Zn}$ & $\mathrm{Cu}$ & $\mathrm{Zr}$ \\
\hline $548-34-4,50-52$ & 687 & 110 & 8 & 20 & 16 & 17 & 19 & 9 & 10 \\
$35-2,6-8$ & 721 & 80 & 9 & 12 & 14 & 8 & 15 & 7 & 6 \\
$35, \mathrm{CC}^{\mathrm{a}}$ & 1176 & 678 & 54 & 1600 & 1632 & 20 & 187 & 202 & 31 \\
$35, \mathrm{CC}^{\mathrm{a}}$ & 1355 & 1884 & 144 & 3086 & 2038 & 27 & 268 & 355 & 28 \\
$35, \mathrm{CC}^{\mathrm{a}}$ & 1193 & 803 & 74 & 2380 & 2065 & 71 & 227 & 248 & 37 \\
$35, \mathrm{CC}^{\mathrm{a}}$ & 1062 & 2590 & 168 & 247 & 260 & 27 & 132 & 97 & 20 \\
$35, \mathrm{CC}^{\mathrm{b}}$ & 696 & 46 & 7 & 7 & 17 & 14 & 16 & 7 & 7 \\
$36, \mathrm{CC}$ & 834 & 396 & 32 & 86 & 28 & 7 & 66 & 17 & 22 \\
\hline
\end{tabular}

Notes as for Table 4 .

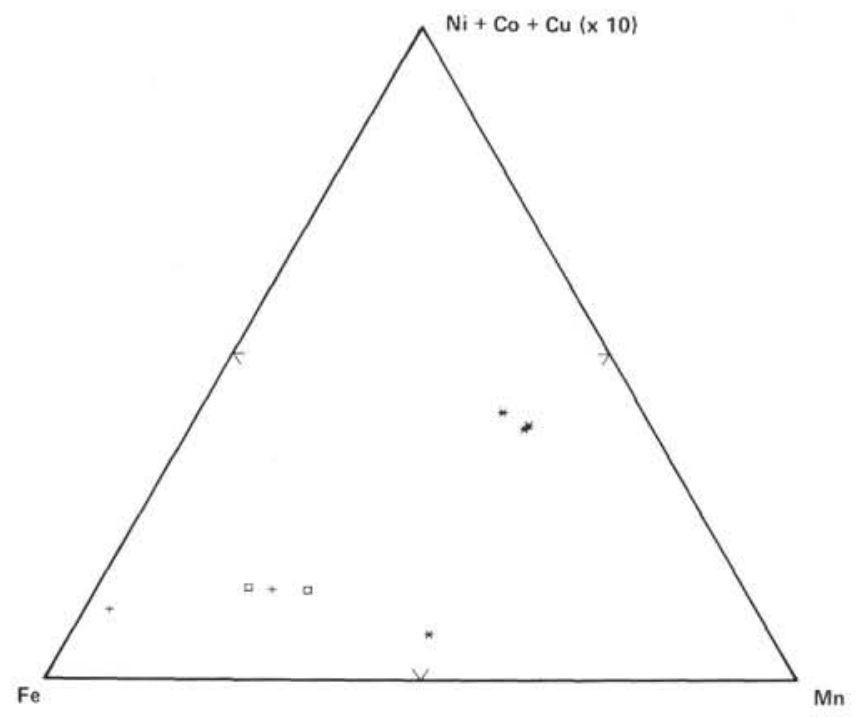

Figure 1I. Ternary diagram of $\mathrm{Fe}-\mathrm{Mn}-(\mathrm{Ni}+\mathrm{Co}+\mathrm{Cu})$ after Bonatti et al. (1972) showing plots of Site 548 samples. Symbols for samples: $\square=34-4,50-52 \mathrm{~cm}$ and $35-2,6-8 \mathrm{~cm}$ (sediments); ${ }^{*}=$ $35, \mathrm{CC}$ a (crust, as defined by Tables $4-6$ ) $;+=35, \mathrm{CC}$ b (as defined by Tables 4-6) and 36,CC.

Table 6. Bulk chemical analyses of sediments from Site 548 (in wt.\%) recalculated on a $\mathrm{CaO}$ - and apatite-free basis.

\begin{tabular}{crrrrrrrrrrr}
\hline $\begin{array}{c}\text { Sample } \\
\text { (interval in cm) }\end{array}$ & $\mathrm{SiO}_{2}$ & $\mathrm{Al}_{2} \mathrm{O}_{3}$ & \multicolumn{1}{c}{$\mathrm{MgO}$} & $\mathrm{CaO}$ & $\mathrm{Fe}_{2} \mathrm{O}_{3}$ & $\mathrm{Mn}_{3} \mathrm{O}_{4}$ & $\mathrm{TiO}_{2}$ & $\begin{array}{c}\text { BaO } \\
\mathrm{Na}_{2} \mathrm{O}\end{array}$ & $\begin{array}{c}\text { LOI at } \\
1000\end{array}$ & $\mathrm{X}$ \\
\hline $548-34-4,50-52$ & 45.8 & 14.6 & 5.62 & 0 & 6.2 & 1.85 & 0.83 & 0.42 & 3.75 & 2065 & 4.8 \\
$35-2,6-8$ & 48.3 & 12.1 & 10.47 & 0 & 8.1 & 3.78 & 0.81 & 0.40 & 5.23 & 10.47 & 2.5 \\
$35, \mathrm{CC}^{\mathrm{a}}$ & 14.5 & 10.5 & 7.42 & 0 & 16.1 & 44.10 & 0.56 & 0.65 & 3.31 & 2.76 & 16.3 \\
$35, \mathrm{CC}^{\mathrm{a}}$ & 6.5 & 9.7 & 8.09 & 0 & 18.3 & 47.44 & 0.43 & 1.24 & 1.62 & 6.63 & 22.6 \\
$35, \mathrm{CC}^{\mathrm{a}}$ & 16.8 & 7.6 & 12.49 & 0 & 16.3 & 34.91 & 0.49 & 0.54 & 1.25 & 9.55 & 21.1 \\
$35, \mathrm{CC}^{\mathrm{a}}$ & 12.6 & 4.6 & 4.05 & 12.34 & 31.4 & 32.28 & 0.29 & 2.11 & 0.40 & 0 & 18.9 \\
$35, \mathrm{CC}^{\mathrm{b}}$ & 34.9 & 11.7 & 7.00 & 0 & 5.8 & 2.13 & 0.87 & 0.29 & 4.37 & 32.57 & 4.1 \\
$36, \mathrm{CC}$ & 51.3 & 11.6 & 6.09 & 8.59 & 14.5 & 0.58 & 0.48 & 0.48 & 6.29 & 0 & 12.1 \\
\hline
\end{tabular}

Note: Total $\mathrm{Fe}$ was calculated as $\mathrm{Fe}_{2} \mathrm{O}_{3}$ and total $\mathrm{Mn}$ as $\mathrm{Mn}_{3} \mathrm{O}_{4} \cdot \mathrm{K}_{2} \mathrm{O} \%$ was below lower detection limit. $\mathrm{X}=$ carbonate- and apatite-free fraction (silicates and oxides) contents in the bulk sediments.

a Crust fragments.

b Crust fragments.
Hard white bottom part. 


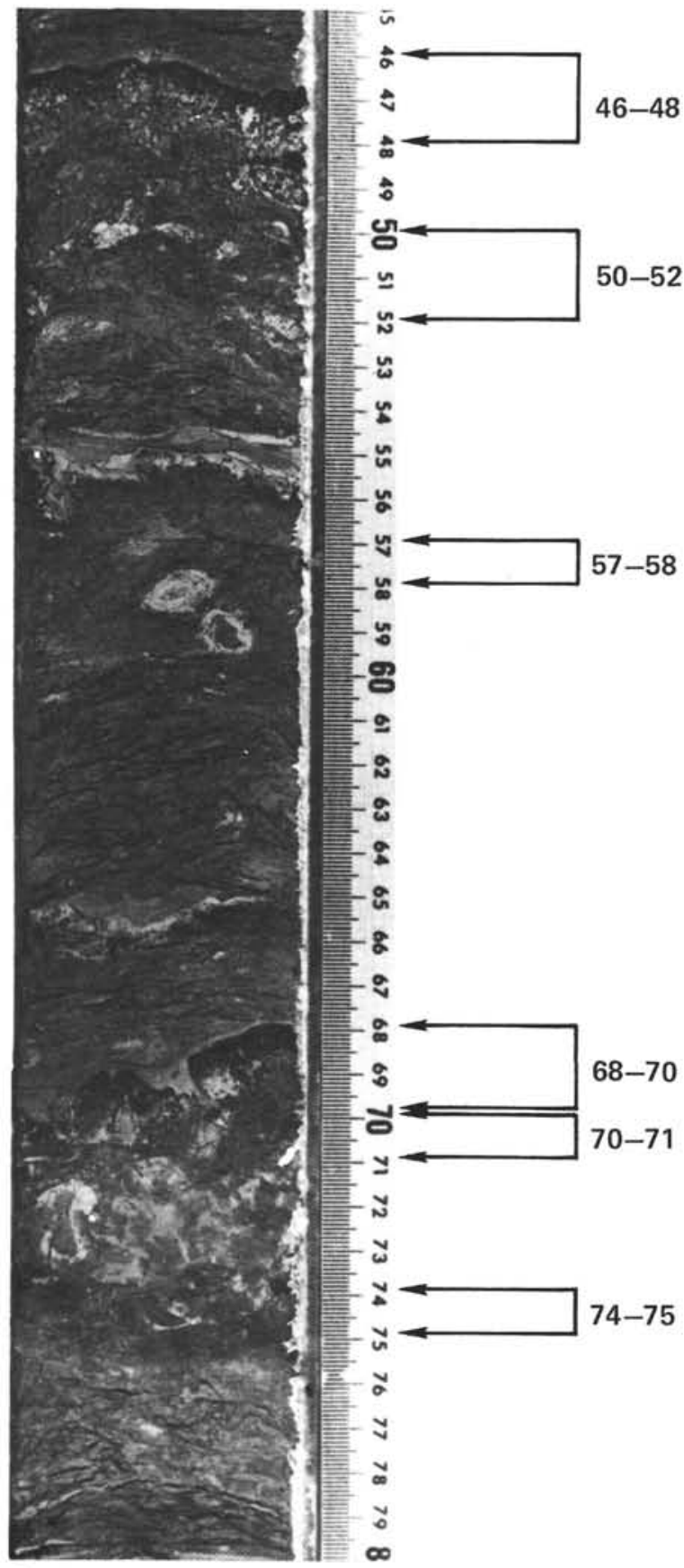

A

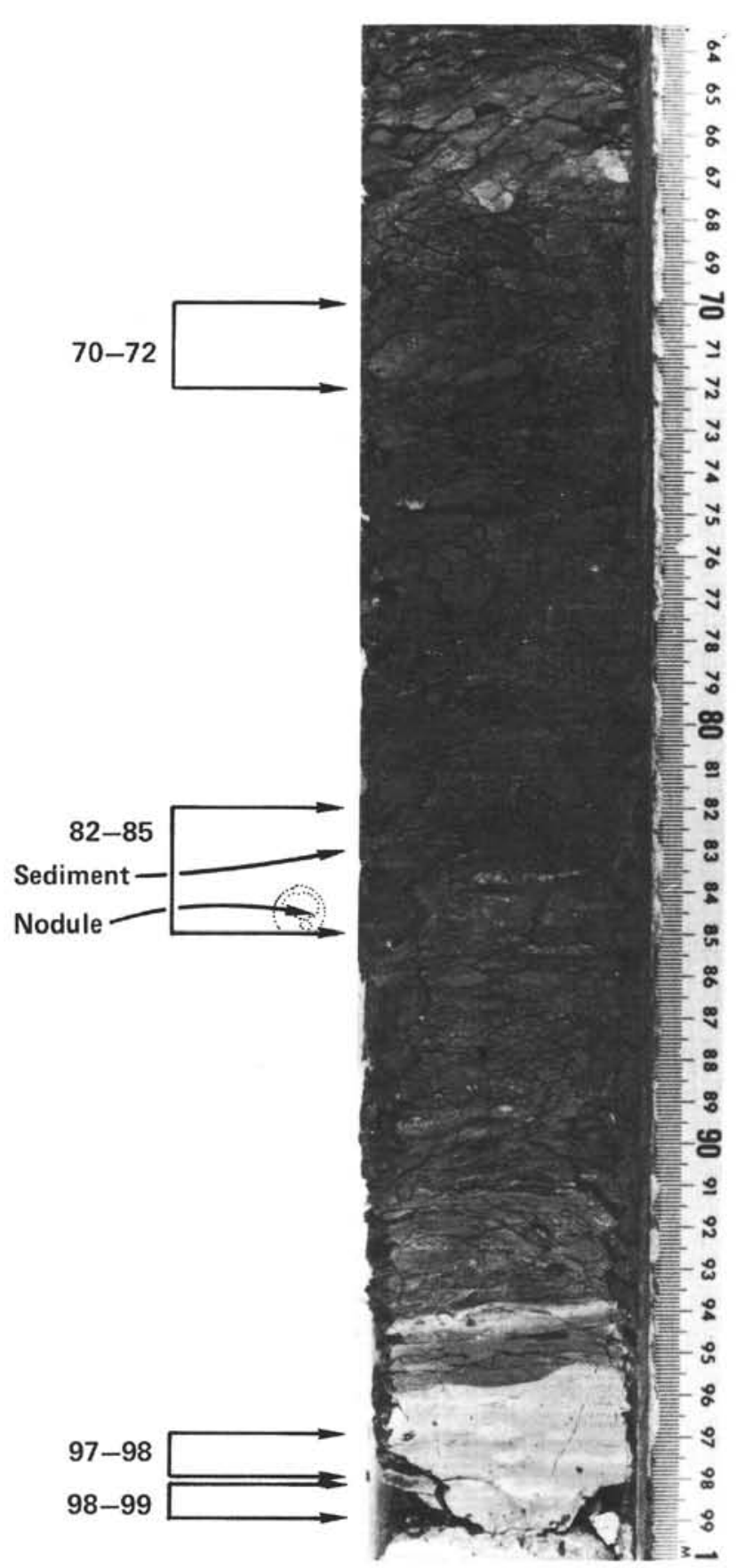

B

Plate 1. Sections of cores at Site 550 showing positions of studied samples. A. 550-24-2, 45-80 cm; middle and upper Eocene deposits. Note structure of two major encrusted layers composed of heterogeneous, white to dark brown, indurated deposits (clays, volcaniclastic components, and zeolites) overlain and coated by black manganese oxides. B. 550-36-3, 64-100 cm: upper Paleocene deposits. The brown clay contains small rounded manganese nodules. The contact between the brown clay and the chalk is marked by a chert layer $(93-100 \mathrm{~cm})$. 

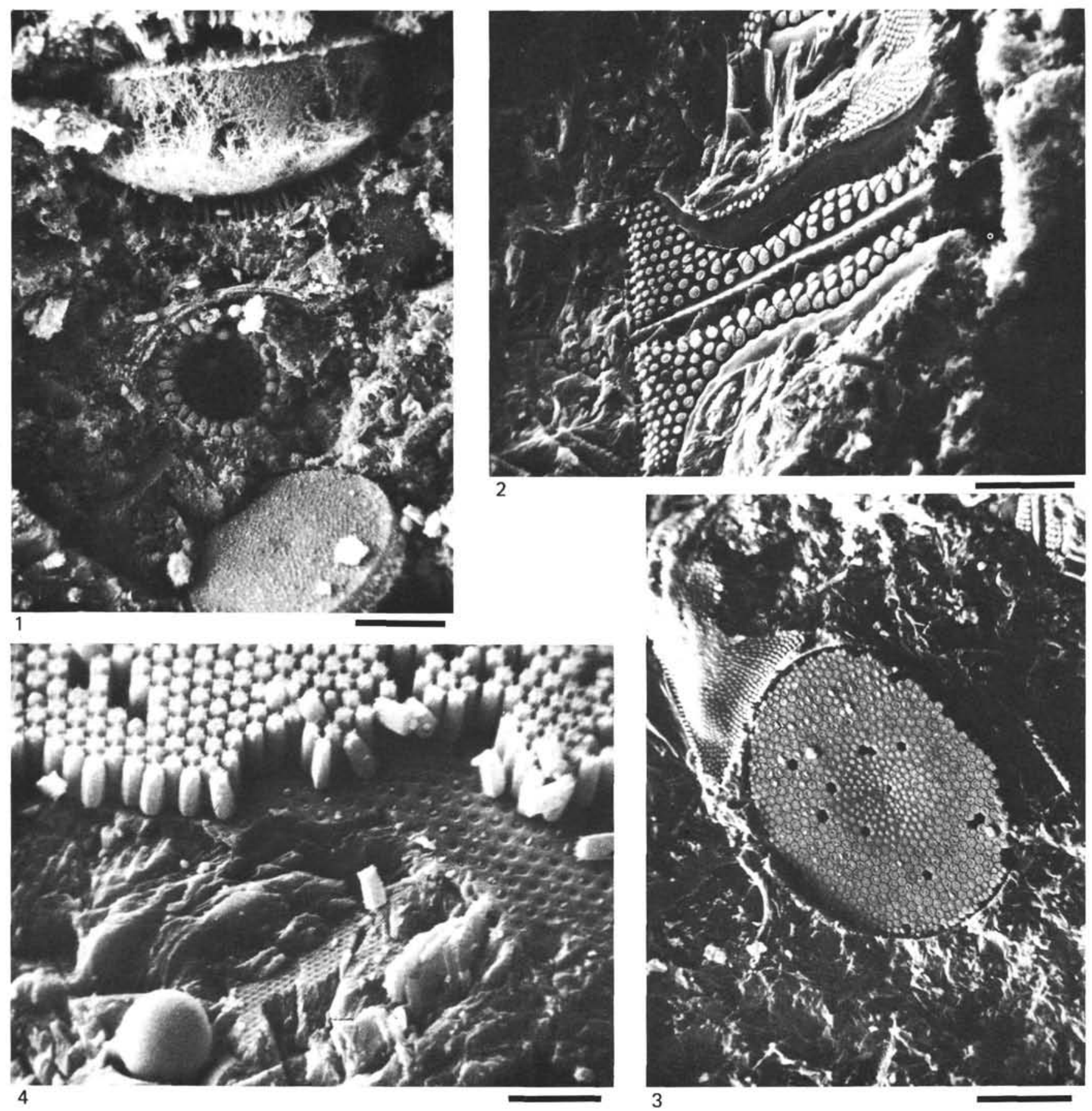

Plate 2. SEM photomicrographs of small broken nodules from the coarse fraction of the upper Paleocene brown clays (550-36-3, 82-85 $\mathrm{cm}$ ). 1. General view of agglutinated and broken biogenic debris (mainly fecal pellets) making up the total mass of the small nodule. The XES analyses confirm that all this debris is composed of $\mathrm{Mn}$ and $\mathrm{Ba}($ scale bar $=20 \mu \mathrm{m}$ ). 2. Sponge fragment (scale bar $=50 \mu \mathrm{m}$ ). 3. A well-preserved diatom completely replaced by Mn oxide (scale bar $=50 \mu \mathrm{m}$ ). 4. Detail of hexagonal structure of diatom surface $(\mathrm{scale}$ bar $=10 \mu \mathrm{m})$. 

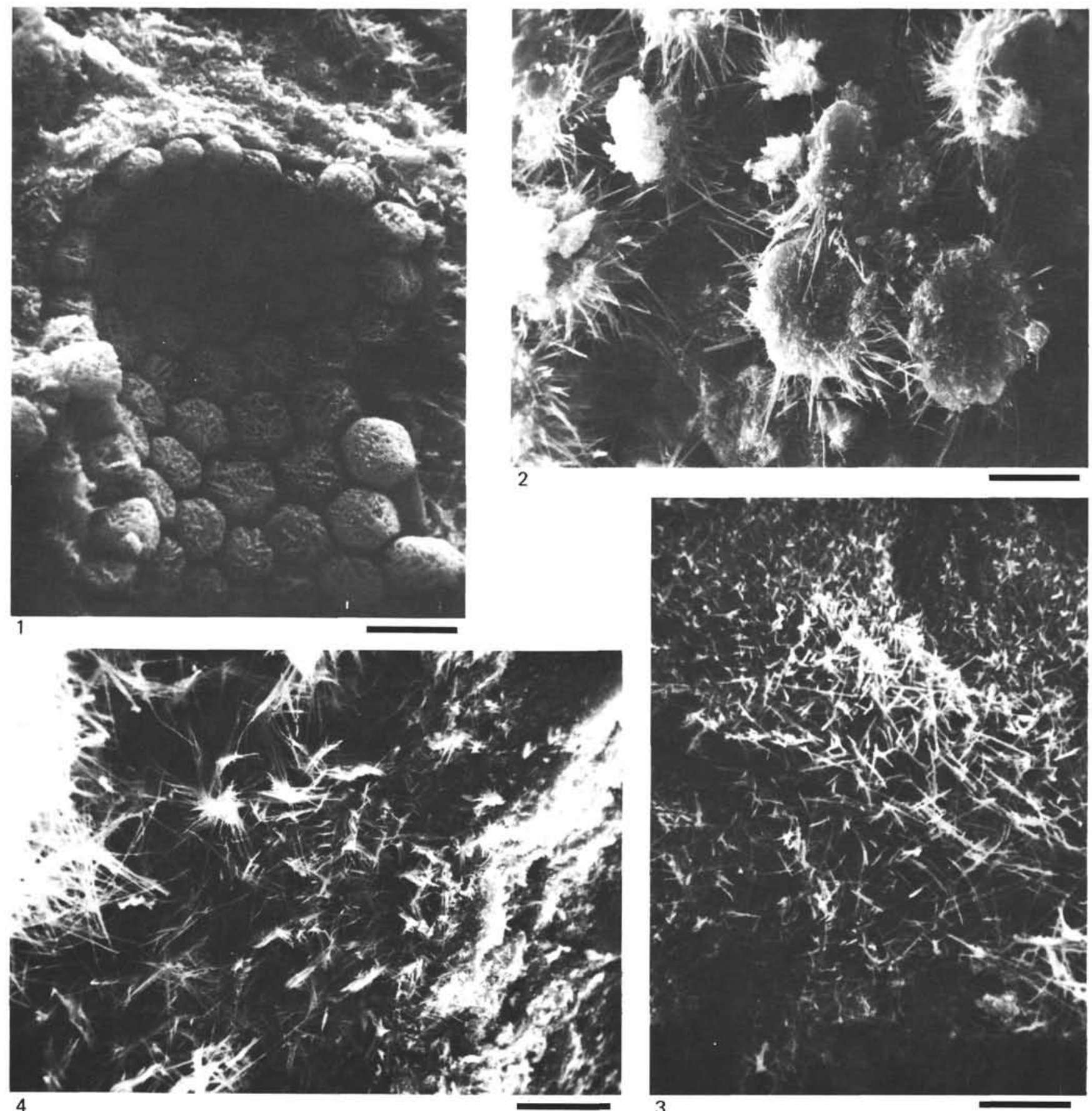

Plate 3. SEM photomicrographs of small broken nodules from the coarse fraction of the upper Paleocene brown clays $(550-36-3,82-85 \mathrm{~cm})$. Note the various morphologies of the crystallites of Mn oxides as todorokite. 1. Small balls of todorokite rods filling the internal test of a biogenic fragment (scale bar $=5 \mu \mathrm{m}$ ). 2. Radiating fine needles of Mn oxides which have formed as overgrowths on biogenic structures (scale bar $=10$ $\mu \mathrm{m})$. 3. Criss-crossing fibers of todorokite in cavities of biogenic fragments (see Plate 2, Fig. 1) (scale bar $=5 \mu \mathrm{m}$ ). 4. Detail of group of todorokite needles (see Plate 6) (scale bar $=10 \mu \mathrm{m}$ ). 


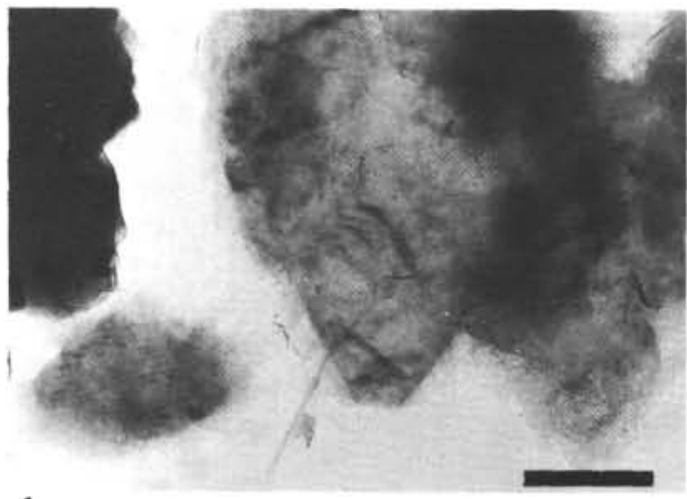

1

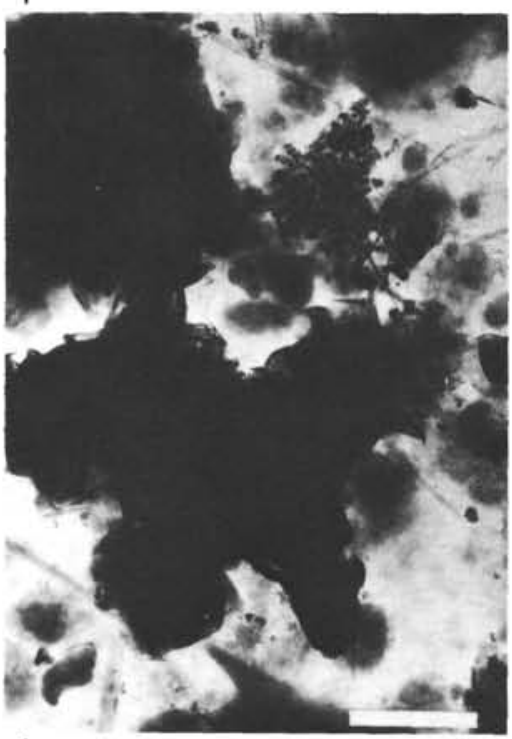

4

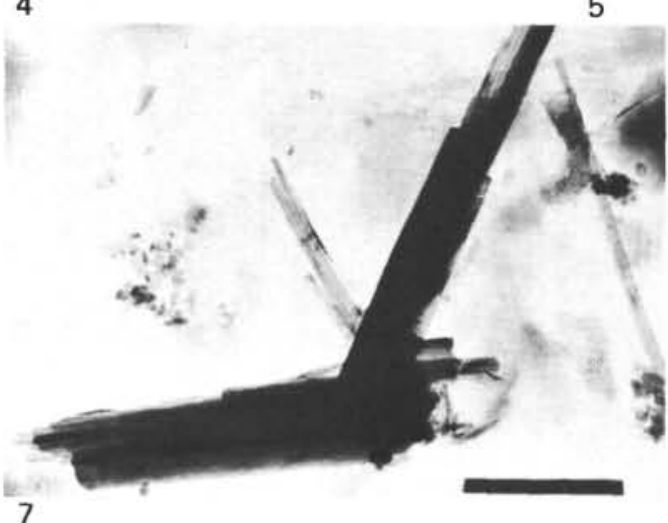

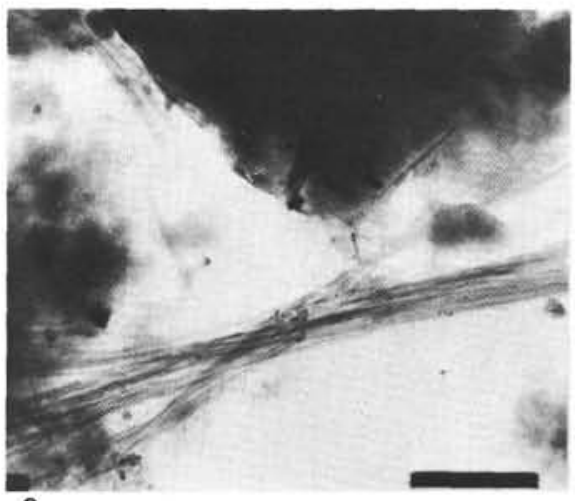

2

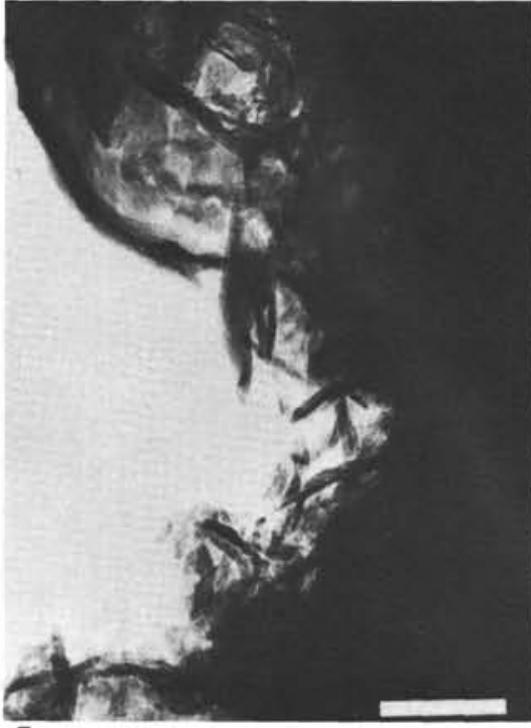

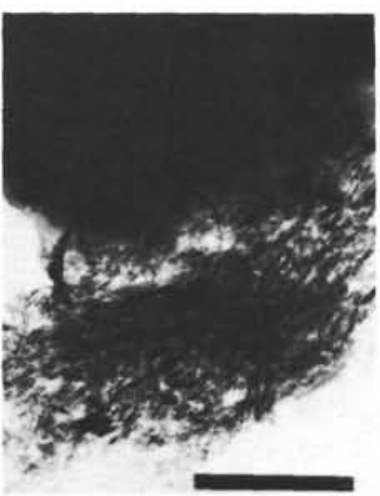

3

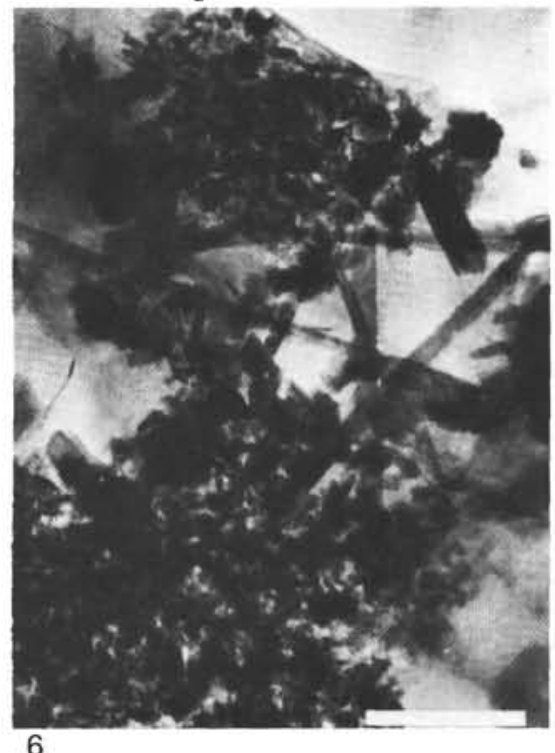

6

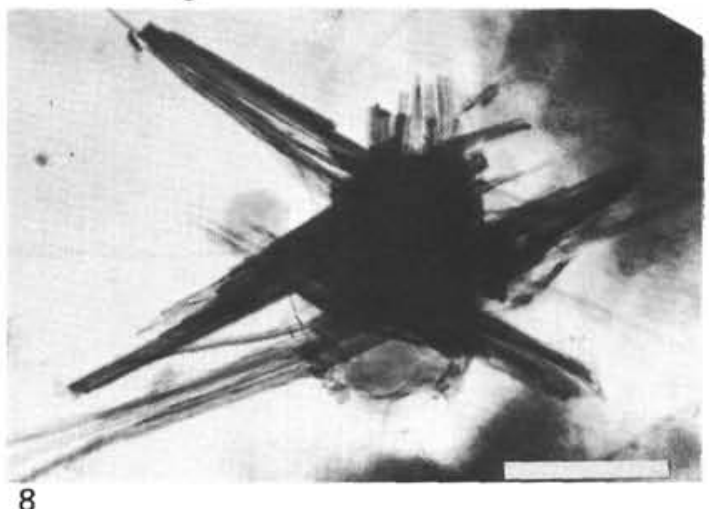

Plate 4. TEM photomicrographs of the dispersed fine fraction from Oligocene marly chalk (Unit 1b) and the upper Eocene encrusted layer (Unit 2a). 1. Sample 550-24-1, 90-94 cm: Oligocene fine marly chalk; altered detrital illite particles with fibrous outlines and a calcareous biogenic fragment (black) (scale bar $=1 \mu \mathrm{m})$. 2. Sample 550-24-2, 46-48 cm: fine fraction of clayey deposits below Mn encrustment; association of smectite particles with flaky outlines and palygorskite fibers in clay fraction of calcareous ooze (scale bar $=0.6 \mu \mathrm{m}$ ). 3 . Sample 550-24-2, 50$52 \mathrm{~cm}$ : aggregate of poorly crystallized iron oxides bracketed to smectites (scale bar $=0.5 \mu \mathrm{m}$ ). $\quad 4$. Sample $550-24-2,68-70 \mathrm{~cm}$ : dense, well-crystallized smectite particles and Fe oxide aggregates. The smectites show curved outlines similar to the authigenic Fe smectites from the volcanicsedimentary deposits $($ scale bar $=1 \mu \mathrm{m}$ ). 5. Detail of 4: the overgrowths of smectite are interlaced clusters of fibers similar to the Fe oxide layered silicate complex (scale bar $=0.12 \mu \mathrm{m}$ ). 6. Detail of 4: aggregates of small crystallite plates of Fe oxides and a few laths of Mn oxides (scale bar $=0.25 \mu \mathrm{m})$. 7. Detail of 4 : crossed laths of well-crystallized Mn oxides in the form of todorokite (scale bar $=0.5 \mu \mathrm{m})$. 8. Sample $550-24-$ $2,74-75 \mathrm{~cm}$ : group of todorokite lathy crystals associated with clays in the fine fraction (scale bar $=0.5 \mu \mathrm{m}$ ). 

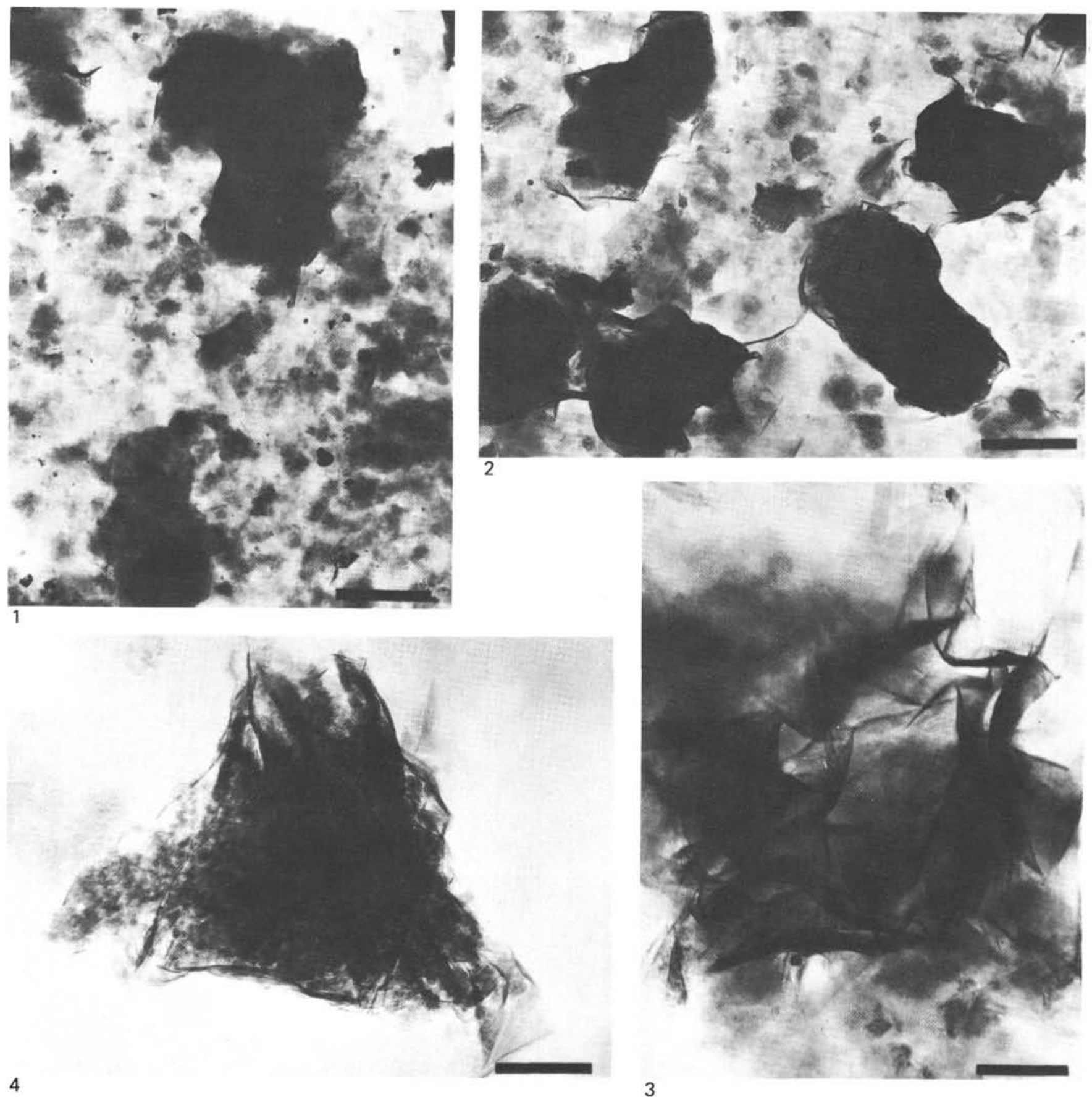

Plate 5. TEM photomicrographs of the dispersed fine fraction from lower Eocene and upper Paleocene deposits (Unit $2 \mathrm{a} / 2 \mathrm{~b}$ boundary). 1. Sample 550-34-1, 50-52 cm: lower Eocene marly chalk; fine fraction containing large smectites with cotton-like, curved edges and small particles of flaky smectites and a few lath-shaped palygorskite crystals (typical clay fraction of calcareous ooze) $($ scale bar $=1.5 \mu \mathrm{m})$. 2 . Sample 550-35-1, 50-52 cm: upper Paleocene mudstone; the large smectite particles with very curly edges associated with aggregates of siliceous globules $($ scale bar $=1 \mu \mathrm{m})$. 3. Detail of 2: morphology of slightly crumpled authigenic smectite particle with diffuse edges $($ scale bar $=0.5 \mu \mathrm{m})$. 4. Detail of 2: cristobalite lepisphere at edges of smectite and siliceous globules (scale bar $=0.16 \mu \mathrm{m}$ ). 


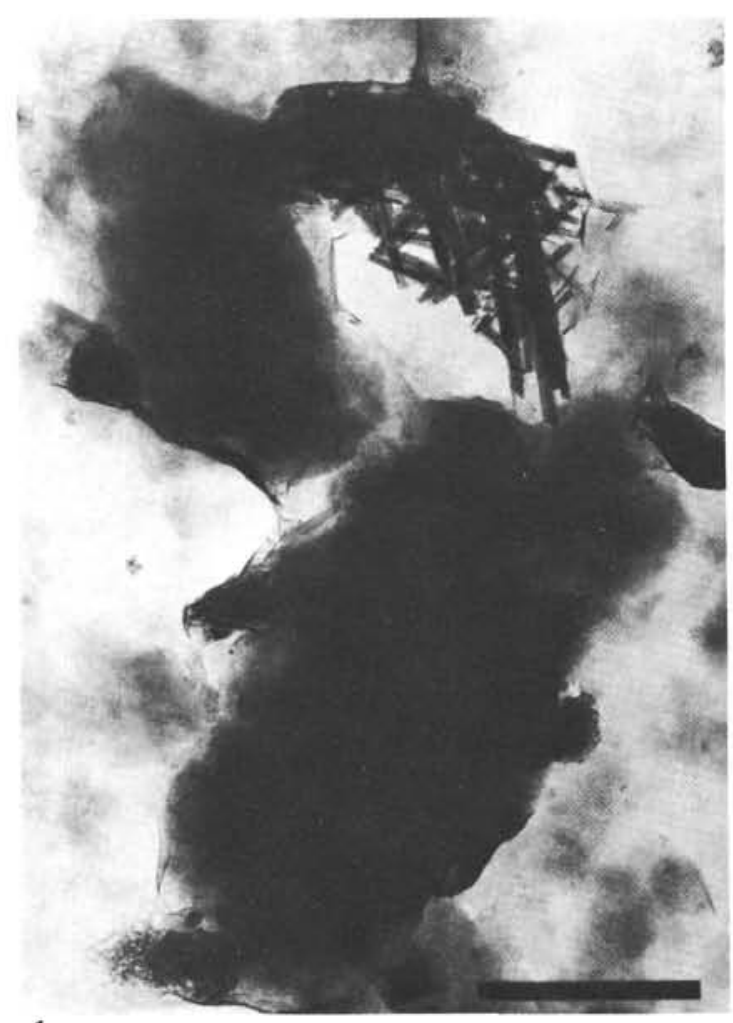

1

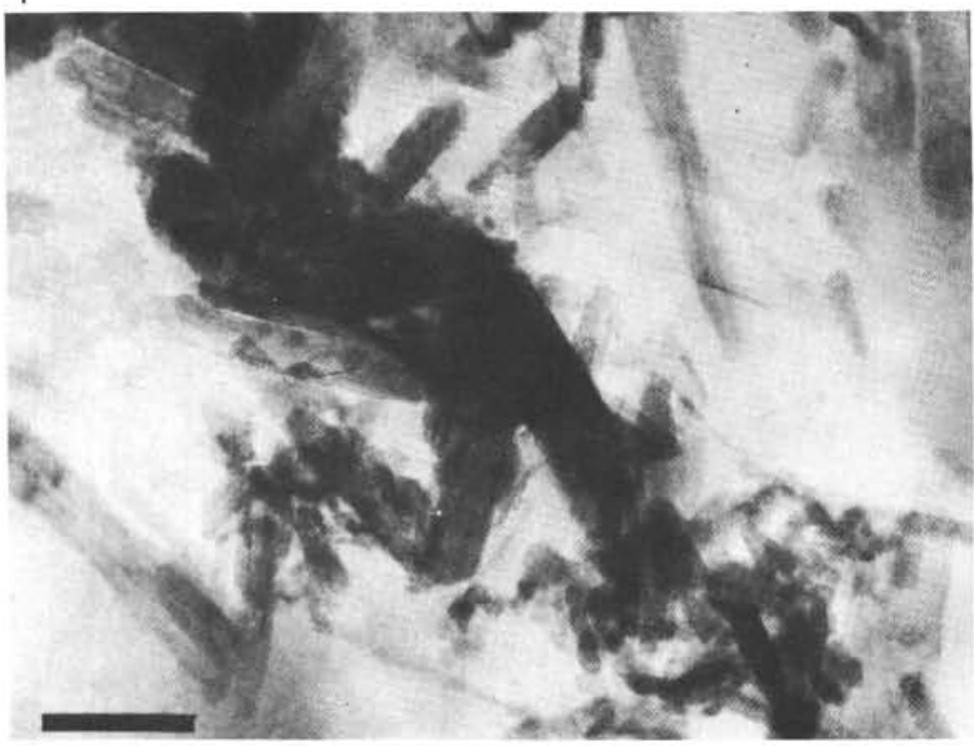

4

2
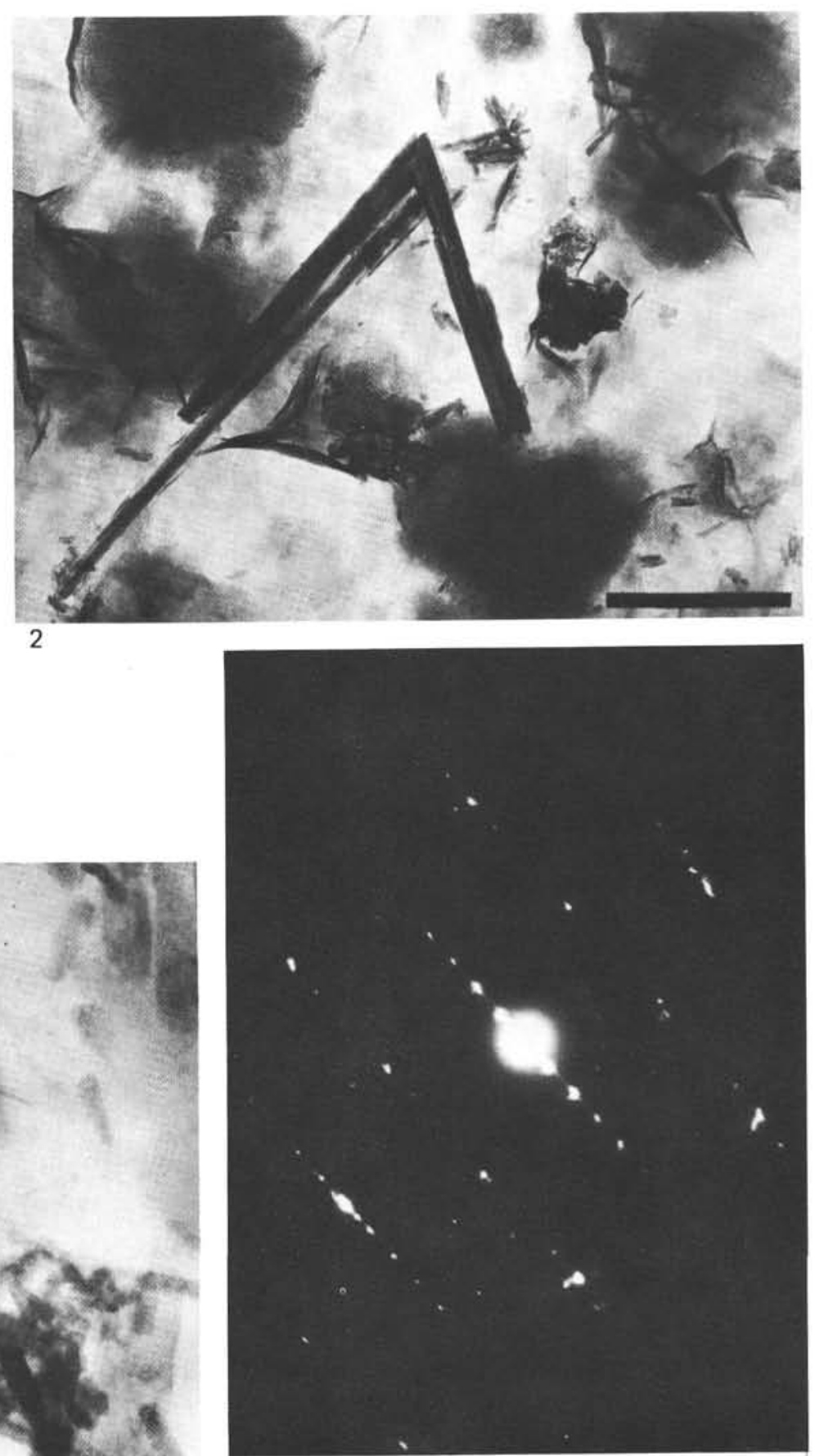

3

Plate 6. TEM photomicrographs of dispersed fine fraction from upper Paleocene brown clays (Unit $2 \mathrm{~b}$ ). 1. Sample 550-36-3, 50-52 cm: large smectite particles with diffuse and slightly rolled edges, bunches of siliceous granules, and well-crystallized radiating todorokite laths (scale bar $=1 \mu \mathrm{m})$. 2. Sample 550-36-3, 82-85 cm: smectite particles with fibrous overgrowths and long platy needles of todorokite (scale bar $=1 \mu \mathrm{m})$. 3. Diffraction pattern from the platy fiber of todorokite in Figure 2 above, which is similar to those given by Arrhenius and Tsai (1981). 4. Detail of 2: very small, flat lath-like crystallites of todorokite. Magnification of the micrograph shows striation features and ribbon structures of the manganate (scale bar $=0.1 \mu \mathrm{m}$ ). 

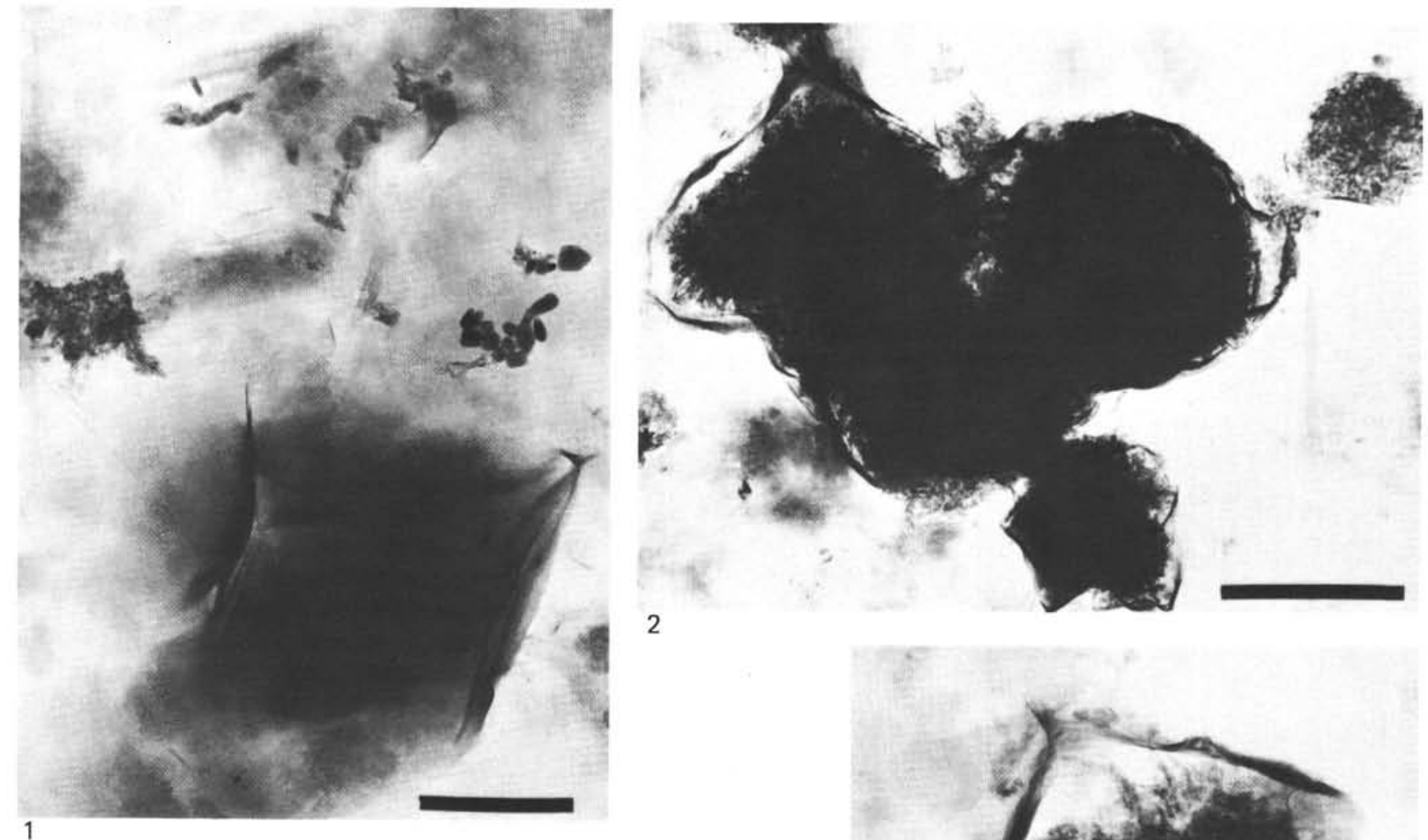

2
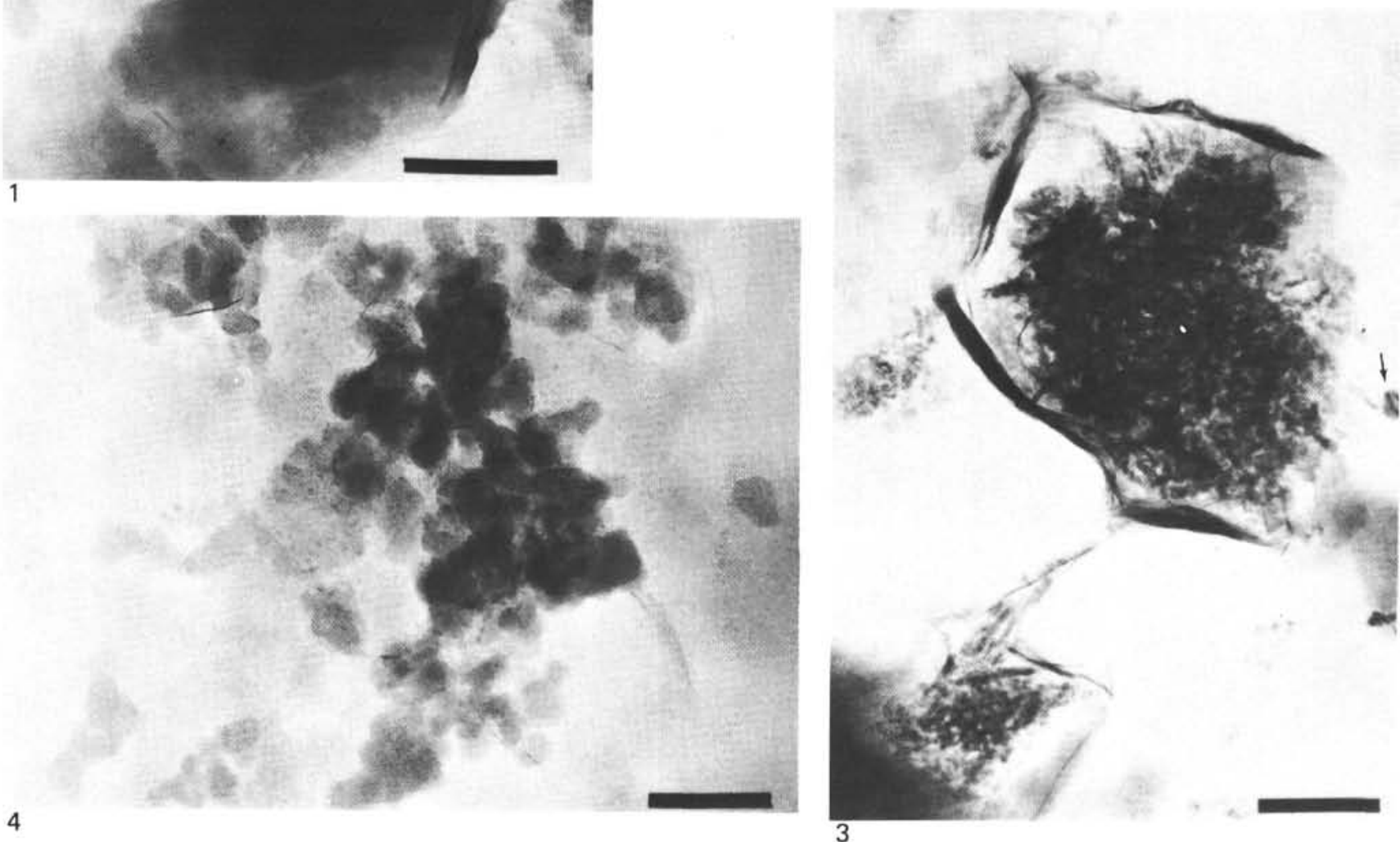

Plate 7. TEM photomicrographs of the dispersed fine fraction from the upper Paleocene chert and chalk (Unit 3a). 1. Sample 550-36-3, 98$99 \mathrm{~cm}$ : smectite particle with diffuse, slightly curly edges with flaky overgrowths and small clusters of granular cristobalite $(\mathrm{scale}$ bar $=$ $0.5 \mu \mathrm{m}$ ). 2. Sample 550-38-1, 48-50 cm: association of authigenic smectite layers and cristobalite lepispheres making dense aggregates (scale bar $=1 \mu \mathrm{m})$. 3. Detail of 2: bunch-like, granular cristobalite and associated bent smectite layers; occurrence of a few very small detrital particles (arrow) (scale bar $=0.3 \mu \mathrm{m})$. 4. Detail of 2 : high magnification of the cristobalite granules $($ scale bar $=0.1 \mu \mathrm{m}$ ). 